\title{
Reconstruction of the Vegetation and Environment during Different Climatic and Sociotechnical Conditions of the Last 3000 Years in Southwestern Hungary
}

\author{
Katalin Náfrádi1 ${ }^{1}$ Pál Sümegi1,2, Gusztáv Jakab³ ${ }^{3}$, Gergő Persaits¹, Tünde Törőcsik1 \\ ${ }^{1}$ Department of Geology and Palaeontology, University of Szeged, Szeged, Hungary \\ ${ }^{2}$ Hungarian Archaeological Institute, Budapest, Hungary \\ ${ }^{3}$ Institute of Environmental Science, Szent István University, Szarvas, Hungary \\ Email: nafradi@geo.u-szeged.hu
}

Received 17 March 2014; revised 16 April 2014; accepted 29 April 2014

Copyright (C) 2014 by authors and Scientific Research Publishing Inc.

This work is licensed under the Creative Commons Attribution International License (CC BY). http://creativecommons.org/licenses/by/4.0/

(c) (i) Open Access

\begin{abstract}
Sedimentary basins such as Lake Baláta in Southwestern Hungary provide information about the development of lake-bog systems, the climate change through time and the environment of the surrounding area. The present study provides combined palynological, anthracological and macrobotanical data regarding climatic, vegetation and hydrological changes of a protected area for the last $\mathbf{3 0 0 0}$ years. Lake Baláta is a sedimentary basin developed in a wind-blown yardang system in Southwestern Hungary. Due to its deeper location and the higher groundwater-level, the boggy lake functioned as a sediment catch. Geological drilling with an auger head drill provided an undisturbed sediment core. During the laboratory analysis different methods, such as sedimentological, geochemical, macrofossil, pollen and charcoal analysis were applied. The different stages and the evolution of the lake-bog system and the vegetation around the lake could be reconstructed and human impact was detected for the last $\mathbf{3 0 0 0}$ years. Human impact and the transformation of vegetation was detected from the Early Iron Age $(900 / 800 \mathrm{BC})$. Human impact reached its maximum during the 10th and 12th centuries when extent plant cultivation and grazing field zones were created. Climate change, increasing precipitation and consequently forest regeneration started in the 13th and 14th centuries. Parallel to this human impact decreased in the study area that indicates the reduction of the population and agrarian activity. Later at the beginning of the 15th century human impact increased again and remained significant until to the 16th century.
\end{abstract}

\section{Keywords}

Anthracology, Macrobotany, Palaeoecology, Pollen Analysis, Southwestern Transdanubia, Hungary

How to cite this paper: Náfrádi, K., et al. (2014) Reconstruction of the Vegetation and Environment during Different Climatic and Sociotechnical Conditions of the Last 3000 Years in Southwestern Hungary. American Journal of Plant Sciences, 5, 1557-1577. http://dx.doi.org/10.4236/ajps.2014.511170 


\section{Introduction}

On the basis of palaeoclimatological analysis, during the last 3000 years climatic changes became more intense compared to the first part of the Holocene. Consequently, significant and cyclic changes of temperature and precipitation developed on a global and regional level. These former climatic changes had a strong effect on the vegetation and human communities. At the same time, the undulating climatic change causes alterations in the composition of cultivated plants and forest assemblages, in forest management and in the relationship of human communities and arboreal vegetation. In order to detect the different climatic phases, vegetation changes and the relationship between forest composition and human communities, a more complex elaboration is necessary among disciples. By the comparative analysis of sedimentological, geochemical, macrobotanical, pollen and athracological analysis, it is possible to reconstruct the natural development of an area and human impact on the vegetation as well.

Anthracological, macrobotanical and pollen analytical study such that have not been conducted in the eastern part of the Alps, in the Carpathian Basin. However, pollen analyses of sedimentary basins indicate deliberate human impact on forest composition from the Neolithic and Copper age [1]-[4], anthracological analysis of woody remains from archaeological sites was not performed in these studies so we have little information about the human impact on forests and about the utilization of wood of prehistorical and historical cultures.

On the basis of the previous archaeological and palaeoecological analyses, in terms of the vegetation development and the relationship of human populations and forests, the most interesting region is the southwestern part of Transdanubia. This area is highly important since smaller lakes and peatlands are frequent in the region that functioned as sedimentary basins. Around 1200 smaller and larger lakes are located; one of the largest is Lake Baláta.

In this area, populations of the earliest Iron Age culture (900/800 BC) [5]: people of the Hallstatt culture settled down. After that inhabitant of the Celtic (450/400 BC-AD) and the Imperial period (40 BC-422 AD), Huns from the migration period (400-454 BC), Germanic tribes (454-568 AD), Avar (568-794/829 AD) and Hungarians (895/896 AD) [5] appeared. According to the settling down of these populations, human impact on the vegetation, including arboreal vegetation, could be reconstructed. The area has a transitional climate between sub-mediterranean and continental type that is reflected in the diverse vegetation. The transition zone of Tilia tomentosae-Quarcetum petraea-cerris with Castanea sativa, Querco petraea-Carpinetum saladiense, Quercetum robori-cerris, Viccio-Fagetum, and mixed pine forests of Erico-Pinion developed [6]-[9]. The above mentioned cultures that already used tools made of iron lived in different areas surrounded by dissimilar arboreal vegetation so we had the opportunity to reconstruct the forest management of these different human populations. We aimed to reconstruct the development and the environment of this unique, protected site, Lake Baláta in the Southwestern Transdanubian area through time and the consequences of climatic change on vegetation. Furthermore, our goal was to determine the relationship of men and their environment and the development of arboreal vegetation during the last 3000 years. This is a time period, where human techniques and the technical development transformed the economic conditions, farming opportunities and forest management. We attempt to give answer to the question that besides climatic change what sort of human impact evolved in the mosaiclike environment due to the technical development, the change of the organization of communities and the cultural traditions. In order to detect human impact on forest ecosystems we performed anthracological analysis of samples deriving from archaeological sites besides the sedimentological, pollen analytical and macrobotanical analysis of the sedimentary basin in the vicinity of the archaeological sites. Analysis of samples deriving from the sedimentary basin gives information about the local, while charred wood remains deriving from the archaeological sites (refuge pits, graves, residues of houses) indicate the local arboreal vegetation. So by combining the different methods we can perform a complex palaeoecological reconstruction.

\section{Study Area}

The study area (46.311738 N, 17.206920 E) is located in the southwestern part of the Carpathian Basin in a hilly and partly flatland environment (Figure 1). The highest point of the region is $338 \mathrm{~m}$ a.s.l. The base rock in the hilly area is tertiary marine sediments with Pleistocene loess, sand and fluvial sediments above it. The climate of the region is Atlantic-alpine, sub-Mediterranean and continental [9]. The precipitation is higher than evapotranspiration and despite of the higher annual temperature $\left(9.8^{\circ} \mathrm{C}\right)$ the water balance of the area is positive. Besides the geological, hydrogeological and geomorphological conditions this positive water balance plays an 


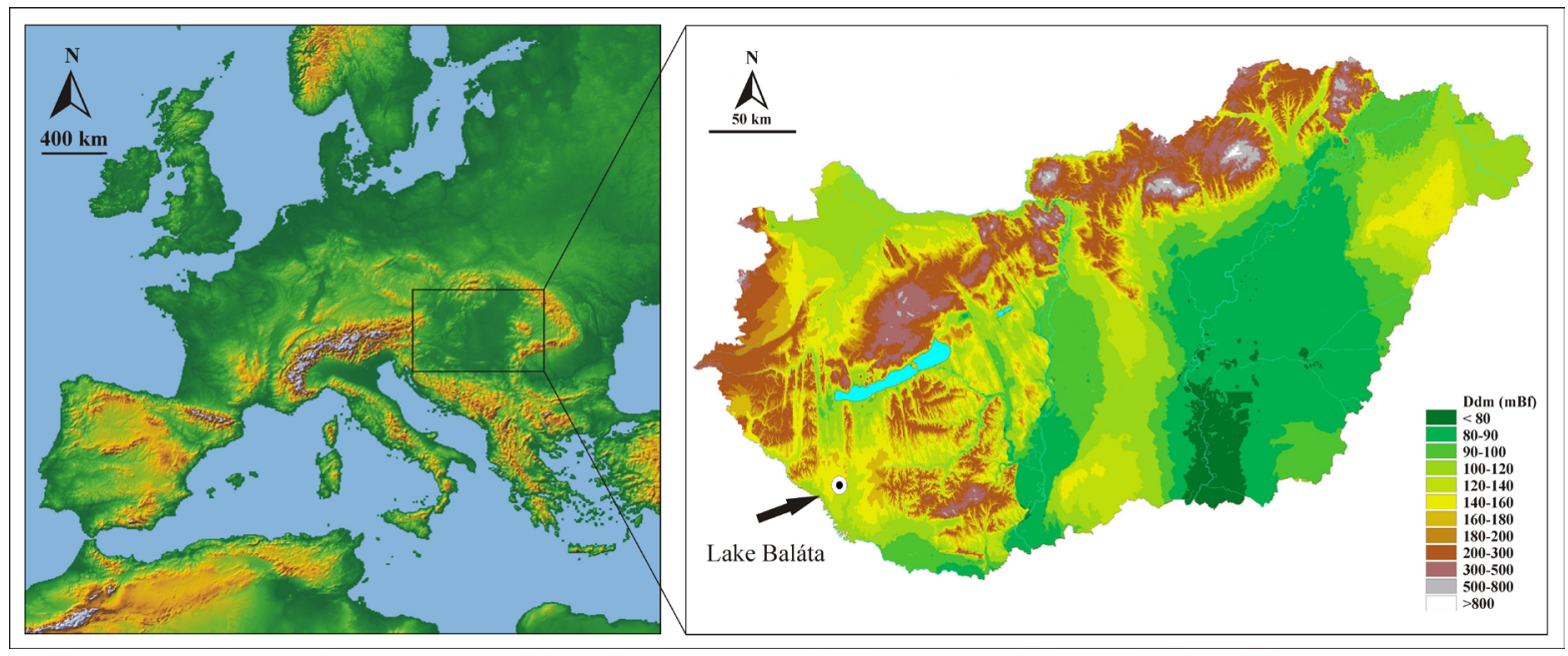

Figure 1. The location of Lake Baláta in Southwestern Transdanubia, Hungary.

important role in the formation of lacustrine, boggy and marshy areas, including our study area, Lake Baláta. As a result of the base rock, climate, vegetation and water circulation hydromorp soil developed in the valley, while in elevated areas brown forest soil evolved [10].

Lake Baláta is a conservation area since 1942 and strictly protected since 1954. The lake system developed in a sedimentary basin with Pleistocene fluvial alluvial fan and Pleistocene sand above it where long blowoutyardang system evolved [10]. The lake system consisted of small patches of water table, floating mats, peatland spots and lakeside marshlands. The surface of the water table is rather small because floating mat (Glycerietum maximae, Scirpo-Phragmitetum, Thelypteridi-Typhetum augustifoliae), willow-swamp (Calamagrostio-Salicetum cinereae), reed (Scirpo-Phragmitetum), swamp (Caricetum elatae) and different reed grasses (Spirodelo-Aldrovandetum, Nymphaeetum albo-luteae) cover it. The bog system is surrounded by alder fernwood (Alnetea glutinosae) and oak-ash-elm gallery forest (Fraxino pannonicae-Ulmetum). On sand-dunes, oak forest (Quercetum-cerris) and on fresh areas oak-hornbeam forest (Quercetum-Carpinetum) developed [6]-[9].

One of the most important plants is waterwheel plant (Aldrovanda vesiculosa), but other plant curiosities occur as well, like purple marshlocks (Comarum palustre), small bur-reed (Sparganium minimum), marsh seedbox (Ludwigia palustris), bogbean (Menyanthes trifoliata) and caldesia (Caldesia parnassifolia). The diverse fauna [11] typical in Central Europe is very significant and besides its significant bird fauna [12], the unique black version of black European vipera (Vipera berus var. prester) is present that is very rare in the Carpathian Basin.

The archaeological sites are located in Zala County, in Southwestern Transdanubia to the north of Lake Baláta (Figure 2). The excavations started in 2002. Findings of several ancient cultures were found at the archaeological excavations, the earliest belong to the Starčevo culture, Middle Neolithic (5200-4790 cal BC) [13]. We focused on archaeological sites that anthracological material derive from Iron Age objects and younger in order to compare our results to the pollen analytical and macrobotanical data of Lake Baláta. Most of the sites are situated on the southern side of north-south oriented natural elevations. Two sites are located on the northern part of the hilly area.

\section{Methods}

\subsection{Sedimentological and Geochemical Analysis}

The sampling of a $260 \mathrm{~cm}$ deep, undisturbed sedimentary sequence of the basin of Lake Baláta was carried out using a 5 cm-diameter Russian-type corer [14]. Overlapping cores were extracted conforming to the general practice in Quaternary palaeoenvironmental studies [15]. Coring was carried out in the central part of the lake-peatland system, now occupied by waterwheel (Spirodelo-Aldrovandetum) community. Samples taken between the depths of 260 and $4 \mathrm{~cm}$ were subjected to sedimentological, geochemical, plant macrofossil and pollen analyses. The Psimpoll program [16] was used for plotting the analytical results. The main lithostratigraphic features of the sedimentary sequence were determined and analyzed. For the description of the cores, the 


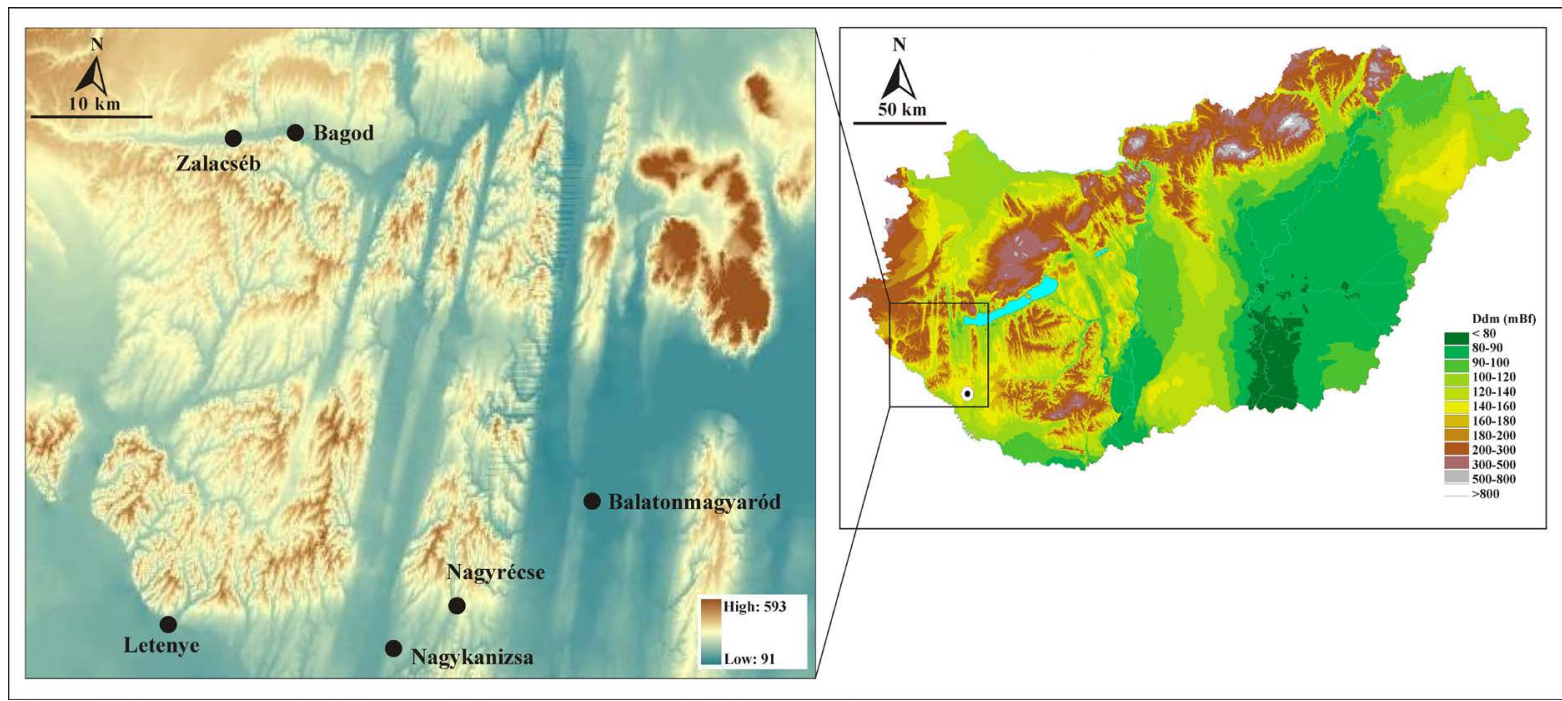

Figure 2. The location of the archaeological sites in Southwestern Transdanubia, Hungary.

internationally accepted system and symbols of Troels-Smith, developed for unconsolidated sediments, was adopted [17].

The organic content of the core samples were estimated by loss-on-ignition at $550^{\circ} \mathrm{C}$ for 5 hours and the carbonate content by the further loss-on-ignition at $900^{\circ} \mathrm{C}$ for 5 hours [18]. A new, so-called sequential extraction method [19] [20] with a long established history in the analysis of geochemical composition of lacustrine sediments was adopted in our work. From the full procedure the step of water extraction for unseparated samples was sufficient to suit our analytical needs as it was shown by previous works [20] [21]. The most important palaeohydrological and palaeoecological data originates from water extraction samples. Therefore the geochemical results from water extraction samples are shown in this work. Distilled water was purified using a Millipore 5 Plus Water Purification System for water extraction samples. $100 \mathrm{ml}$ distilled and purified water was added to $1.0 \mathrm{~g}$ sample and was shaken for 1 hour [20] and then the water extract elements of $\mathrm{Na}, \mathrm{K}, \mathrm{Ca}, \mathrm{Mg}$, Fe were analyzed using a Perkin-Elmer AAS spectrometer. The results from the geochemical analyses are plotted against depth. Statistical procedures were used to zone the data. Principal components analyses computed on correlation matrices were preformed after logarithmic transformation of the geochemical data [22]. The geochemical zones were identified by cluster analysis of principal components [23] using squared Euclidean distance and Ward aggregation method.

\subsection{Macrofossil Analysis}

For the description of macrofossils a modified version of the QLCMA technique (semi-quantitative quadrate and leaf-count macrofossil analysis technique) of Barber et al. and Jakab et al. [24] [25] was used and the work of Jakab and Sümegi [26]. To obtain concentrations for the macrofossil components, a known amount of marker grains ( $0.5 \mathrm{~g}$ poppy seeds, ca. 960 pieces) were added to the samples. In the diagrams the total number of seeds relates to $20 \mathrm{~cm}^{3}$ sediment, while other macrofossil components are expressed as concentrations (piece $\mathrm{cm}^{-3}$ ).

\subsection{Pollen Analysis}

Imola Juhász presented the preliminary results of pollen analyses of the analyzed sequence [27] [28] for every $16 \mathrm{~cm}$, but we continued the pollen analyses and at last the retrieved cores were also subsampled at 4-cm intervals for pollen analysis in pollen lab of Hungarian Geological Survey at Budapest. A volumetric sampler was used to obtain $1 \mathrm{~cm}^{3}$ samples, which were then processed for pollen [29]. Lycopodium spore tablet was added to each sample in order to determine the concentration of identified pollen grains [30]. A minimum count of 300 grains per sample (excluding exotics) was made in order to ensure a statistically significant sample size [31]. Charcoal abundances were determined using the point count method [32]. The pollen types were identified and modified according [33]-[36], supplemented by examination of photographs [37]-[39] and of reference material 
held in the Hungarian Geological Institute, Budapest.

\subsection{Macroscopic Charcoal Analysis in Archaeological Sites}

During the anthracological sampling process sediment profiles were created at the archaeological sites and it was possible to study the settlement levels of the individual cultures and soil horizons. The charcoal remains collected in the site originate from different archaeological features, among which there are refuse pits, extremely large pits used for clay mining, diverse structural elements of houses such as postholes and foundation trenches and also pits containing nothing but charcoal and ash. The archaeobotanical material was obtained from uniformly $2.7 \mathrm{~kg}$ of samples [40] according to the German standards [41]. We used dual flotating method according to Gyulai [42] using 0.5 and $0.25 \mathrm{~mm} \varnothing$ sieves. The remains were then sorted for archaeological, archaeozoological and archaeobotanical analysis. Charcoal samples were selected and counted. We represent the charcoal fragment counts as after Chabal et al. [43] it makes no difference if we count or weight the amount of charred wood remains in case of floated samples [44]. The age of the charcoal samples were obtained from the archaeologists, according to the archaeological findings. Charcoals were identified using polarization microscope with magnifications $100 \times, 200 \times$ and 500×. The taxon identification was carried out using the reference books of Pál Greguss [45] [46] and Fritz Hans Schweingruber [47].

\subsection{Radiocarbon Analysis}

Dating of the sequence was carried out by conventional radiocarbon dating at the radiocarbon dating facility in Poland. Five samples ( 6 - 10 g peat) of sediment were analyzed for radiocarbon ages. In order to allow comparison with other archaeological data, the dates were calibrated using the Calib 7.0.0. calibration programme [48]. The original dates (14C) are indicated as BP, while the calibrated dates are indicated as cal BC/AD. For a more accurate dating of the lower part of the core, additional radiocarbon measurements are under way.

\section{Results}

\subsection{Radiocarbon Analysis}

On the basis of AMS analysis (Table 1) the sub-Atlantic period comprises the time horizon from the Iron Age to the end of the middle ages due to the Hungarian archeostratigraphy [5]. The sedimentation rate (Figure 3 ) was typical in the profile at the beginning of the Iron Age, $0.6-0.2 \mathrm{~mm} /$ year that complies with the sedimentation rate of the Holocene eutrophic-mesotrophic lakes in Hungary [49].

The sedimentation rate increased significantly, almost doubled $(0.7-1.0 \mathrm{~mm} / \mathrm{year})$ at the boundary of the organic material rich lacustrine and peat formation layer. This is not fortuitous since during the formation of floating mat sedimentation become faster [49] due to the fast vertical and horizontal growing of macrophita vegetation [51] [52]. In this way floating mat occupied the surface of the shallow lake in a relatively short time [53]. On the basis of radiocarbon analysis the organic material rich formations were deposited at the end of the Holocene, from the Iron Age. So there is a 7000 - 8000 years long hiatus between the minerorganic, silt rich layers above the sand that evolved at the end of the Pleistocene and the late Holocene layers. On the basis of the geological results there was not sedimentation from the end of the Pleistocene until to the sub-Boreal chronozone, the beginning of the Iron Age in the study area. The reason for that is there was not water cover, nor lake-bog environment between these time periods.

Table 1. Radiocarbon ages of the core profile of Lake Baláta.

\begin{tabular}{cccccc}
\hline Depth (centimeter) & Sample & UnCal BP years & Cal BC/AD years $(2 \sigma)$ & Cal BP years $(2 \sigma)$ & Laboratory code \\
\hline $21-25$ & reed & $375 \pm 30$ & $1446-1632 \mathrm{AD}$ & $318-504$ & Poz-7989 \\
$41-45$ & reed & $645 \pm 30$ & $1282-1395 \mathrm{AD}$ & $555-668$ & Poz-8071 \\
$61-65$ & redd & $995 \pm 30$ & $987-1151 \mathrm{AD}$ & $799-963$ & Poz-7988 \\
$81-85$ & reed & $2140 \pm 30$ & $353-56 \mathrm{BC}$ & $2005-2302$ & Poz-8092 \\
$101-105$ & reed & $2425 \pm 30$ & $749-404 \mathrm{BC}$ & $2353-2698$ & Poz-7991 \\
\hline
\end{tabular}




\subsection{Sedimentological and Geochemical Analysis}

We could separate 9 sedimentological zones macroscopically in the profile (Table 2) using the Troel-Smith system. Besides this core we analyzed 17 more cores in respect of sedimentological point of view. The presented core characterized most completely the sequence. In case of the other cores the development of the sediment layers was thin, and the organic material rich layers that are very important in respect of macrofossils were poorly developed as well. According to the transect profile (Figure 4) that was created on the basis of all cores, this core profile contain the most complete stratigraphy. The total length of the profile is $2.6 \mathrm{~m}$ and samples were taken by $4 \mathrm{~cm}$ so the total number of samples is 85 .

On the basis of geochemical analysis we could separate 7 zones in the profile (Table 3) that were developed roughly in the same geochemical environment.

The base rock $(108-260 \mathrm{~cm})$ is rich in silt and sand, accumulated during the Pleistocene, and weathered silicate and calcite material dominates in it (Figure 5, BGK-1-5: $260-110 \mathrm{~cm}$ ). Above the base rock a carbonate rich, organic material free clayey silt layer developed. This sediment accumulated in an oligothrophic lake environment and is very similar to the minerorganic siltation lakes in other part of the Carpathian Basin [54]-[56] that accumulated at the end of the Pleistocene. On the basis of the alteration of iron and potassium content it can be correlated to the final, wetland type phase of minerorganic siltation. On these Pleistocene sediments, with significant hiatus, lacustrine-boggy-marshy sediment that accumulated during the last 3000 years deposited (BGK-6-7).

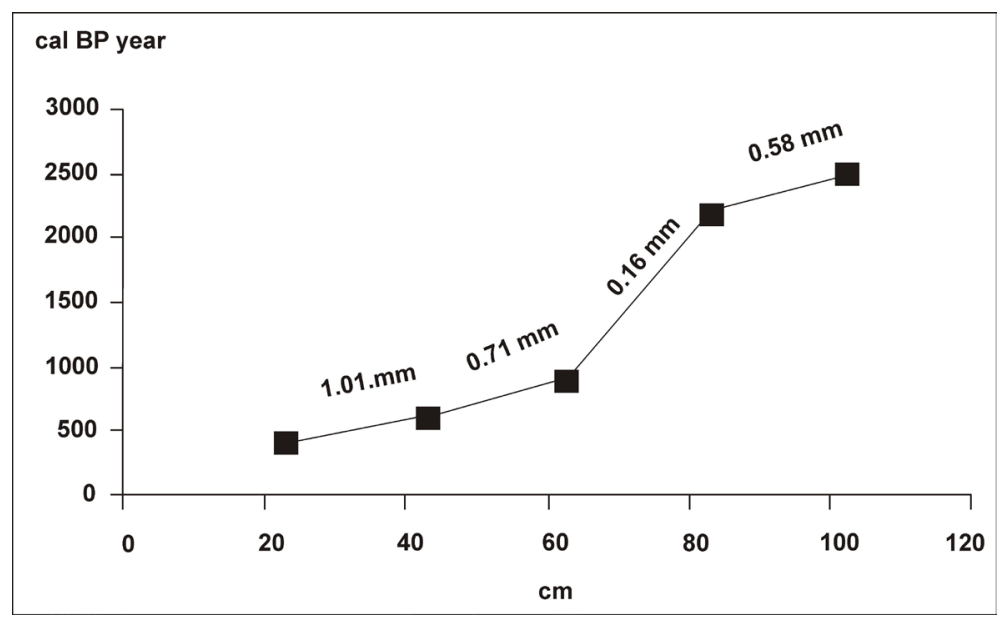

Figure 3. Late Holocene sedimentation rate of the analyzed core sequence from Lake Baláta.

Table 2. Sedimentological description of the core profile of Lake Baláta (after [50]).

\begin{tabular}{cccc}
\hline Depth (centimeter) & Age (Cal BC/AD years) & Troel-Smith category & Lithostratigraphy \\
\hline $0-40$ & $1300-1200$ Cal AD & Th4 & Light brown peat \\
$40-45$ & $1200-1300$ Cal AD & As2 Sh2 & Blackish brown mud \\
$45-70$ & $700-1200$ Cal AD & Th2 Tb2 & Light brown peat \\
$70-100$ & 400 cal BC-700 Cal AD & As3 Th1 & Brownish grey Holocene lacustrine mud \\
$100-108$ & $900-400$ cal BC & As3 Sh1 & Yellow-brown Holocene lake sediment \\
$108-140$ & Lateglacial period & Ag2 As2 & Grey-green Pleistocene lake-marshy sediment \\
$140-240$ & Lateglacial period & Ag3 As1 & Grey-green Pleistocene lake sediment \\
$240-250$ & Lateglacial period & Ga1 & Yellow-brown Pleistocene sand drift layer \\
$250-260$ & Lateglacial period & Ag3 Ga1 & Grey-green Pleistocene lake sediment
\end{tabular}




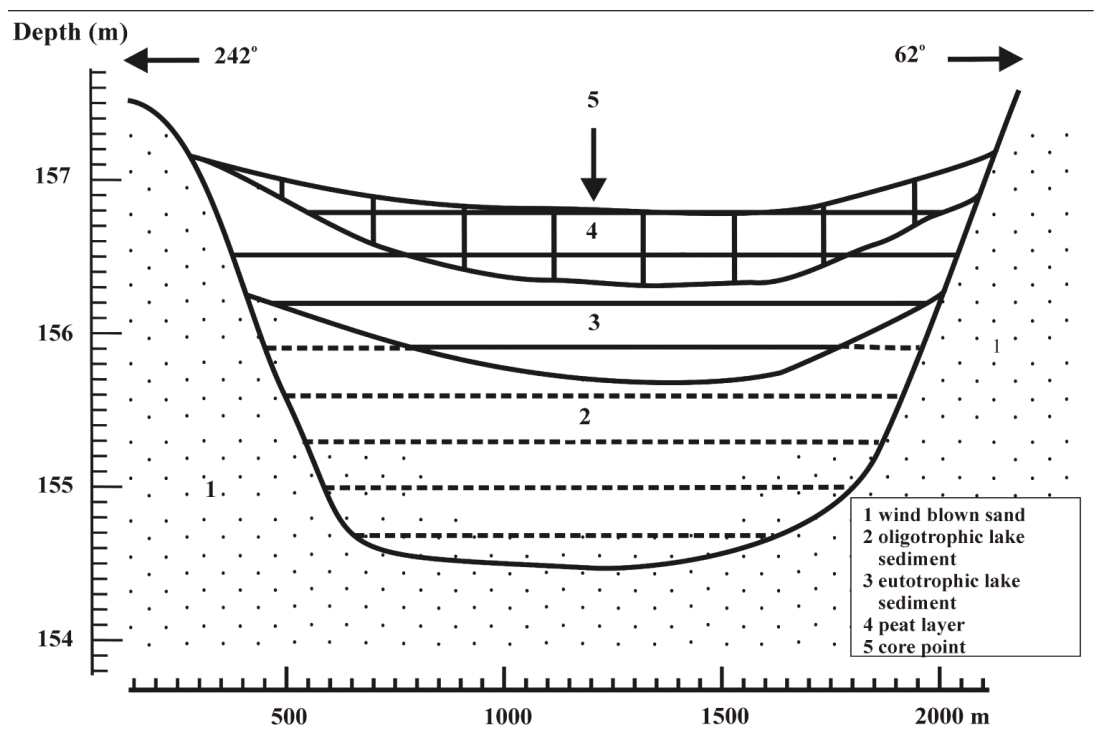

Figure 4. The geological dross-section of the southern basin of Lake Baláta.

Table 3. Geochemical zones and water-soluble element content of the core taken from Lake Baláta.

\begin{tabular}{|c|c|c|c|}
\hline Depth (centimeter) & Age (Cal BC/AD years) & Geochemical zones & Character of geochemical zone \\
\hline $0-60$ & 900-2000 Cal AD & BGK-7 & $\begin{array}{l}\text { Organic material, Ca-, Na-, Mg-content maximum } \\
\text { with a burned K-rich horizon }\end{array}$ \\
\hline $60-110$ & 1000 Cal BC-900 Cal AD & BGK-6 & $\begin{array}{l}\text { Organic material, Na-, K-content and mineral calcite } \\
\text { maximum }\end{array}$ \\
\hline $110-150$ & Lateglacial period & BGK-5 & $\begin{array}{l}\text { Inorganic material maximum, increasing organic } \\
\text { material, K- and Na-content }\end{array}$ \\
\hline $150-210$ & Lateglacial period & BGK-4 & $\begin{array}{l}\text { Significant inorganic substance, Ca-, Mg-, Fe-content } \\
\text { significant }\end{array}$ \\
\hline $210-240$ & Lateglacial period & BGK-3 & $\begin{array}{l}\text { Maximum inorganic substance, no organic material, } \\
\text { significant water-soluble Ca-, Fe-, Mg-content, } \\
\text { carbonate content significant }\end{array}$ \\
\hline $240-250$ & Lateglacial period & BGK-2 & $\begin{array}{l}\text { Maximum inorganic substance, no organic material, } \\
\text { significant mineral carbonate content }\end{array}$ \\
\hline $250-260$ & Lateglacial period & BGK-1 & $\begin{array}{l}\text { Maximum inorganic substance, minimal organic material } \\
\text { content }\end{array}$ \\
\hline
\end{tabular}

In BGK-6 (110 - $60 \mathrm{~cm})$ the organic material content abruptly increased and organic material rich eutotrophic lake sediment accumulated. The carbonate, water-soluble iron, natrium and potassium content of the sediment are high and there is a mineral calcite maximum. On the basis of peat patches floating mat became dominant in the lacustrine environment in this time horizon and eutotrophic lake environment evolved during the Iron Age based on radiocarbon data.

In BGK-7 $(60-0 \mathrm{~cm})$ the organic material content remained significant and closed peat layers accumulated during this horizon. Between 41 and $45 \mathrm{~cm}$ the peat burnt and this layer is appeared as a black ash and soot layer in the peat. This horizon corresponds to the 13th century on the basis of radiocarbon analysis. Its development can be linked to the extremely hot and dry summers in the 13th century [57], although anthropogenic burning cannot be excluded as well. Apart from the potassium peak of the burnt layer, calcium, sodium and magnesium rich peat layer developed in the surface of the flatted lake. On the basis of element content reed-grass, reed (Phragmites), bulrush (Typha) and sedge (Carex) plants were present in a peat forming amount in the sedimentary basin.

\subsection{Macrobotanical Analysis}

Macrobotanical fossils turned up only from $105 \mathrm{~cm}$ towards the surface. The macrobotanical composition of the zones is as follows. 


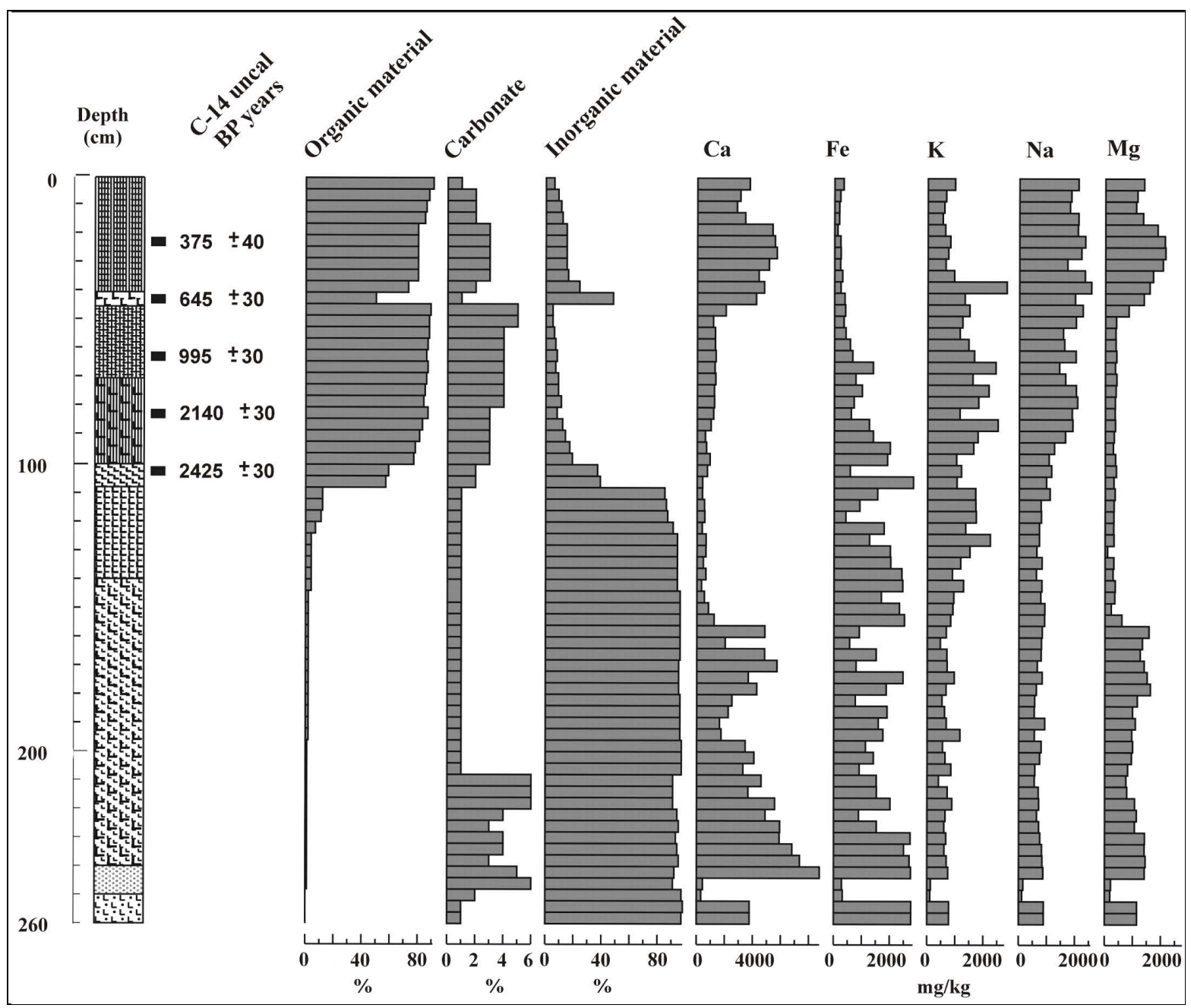

Figure 5. Results of LOI and geochemical analysis of the core from Lake Baláta.

BTM-1 (105 - $90 \mathrm{~cm})$ :

The macrofossil concentration was very low (Figure 6). As a result, a clear water lake environment could develop in the Early Iron Age between 2800 - 2500 bp.

BTM-2 (90 - $70 \mathrm{~cm})$ :

The increasing macrofossil content, the rhizomes of common reed (Phragmites) and tussock sedge (Carex elata), and the increasing number of eggs of water flea (Dalphnia) indicates eutrophication in the zone. A closed marshy zone evolved around the lake, but the water surface could exceed the present state. Broad-leaved pondweed (Potamogeton natans) and water-lily (Nymphaea alba) represent the floating and rooted reed-grass species. The presence of buttercup (Batrachium) indicates that the open water surface was shallow, only 1 - $2 \mathrm{~m}$ deep and probably was warm during the growing period. The occurrence of stonewort (Chara) indicates that the carbonate content of the water was relatively high.

BTM-3 (70 - $60 \mathrm{~cm})$ :

The macrofossil concentration increased in this zone and parallel to it the ratio of reed increased as well. In reed covered parts of the lake the amount of lakeshore bulrush (Schoenoplectus lacustris) and mosses (Bryophyta) were growing. The expansion of water flea (Daphnia sp.) points to intensive eutrophication. Other plant remains are typical in this zone, such as brown flatsedge (Cyperus fuscus), spotted ladysthumb (Polygonum cf. persicaria), large grey willow (Salix cinerea), water mint (Mentha aquatica), broadleaf cattail (Typha latifolia), water dropwort (Oenanthe aquatica) and purple marshlocks (Comarum palustre). Active peat formation, marshy lake environment developed in the lake bed. 


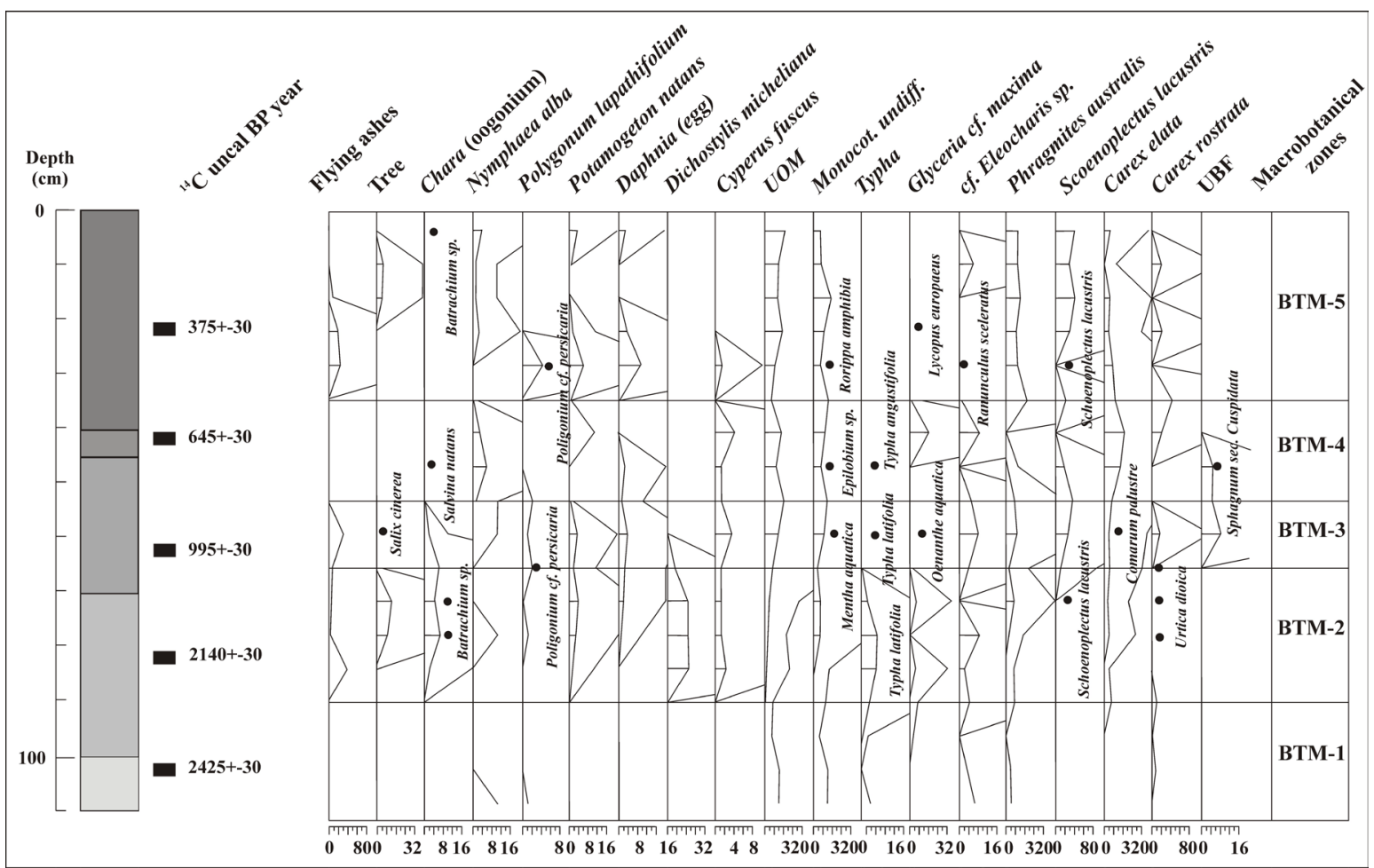

Figure 6. Macrobotanical results from the analyzed core sequence from Lake Baláta. Cirlcles mean sporadic data.

BTM-4 (60 - $45 \mathrm{~cm})$ :

The spread of tussock sedge (Carex elata) and the decrease of reed (Phragmites) and rush (Schoenoplectus) indicate the significant drop of water level. This aridity process reached its peak in the 13th century AD when reed (Phragmites) and rush (Schoenoplectus) disappeared from the profile. The high amount of brown flatsedge (Cyperus fuscus) and spikerush (Eleocharis) remains indicate the parched fen windows as well. The presence of sphagnum (Sphagnum sec. cuspidata) proves the advanced stage of paludification. The surface of this peat layer burned in the 13th century.

BTM-5 (45 - $20 \mathrm{~cm})$ :

A burned layer occurred with low amount of black-brown lacustrine mud between 40 and $45 \mathrm{~cm}$. The low water level at the end of the previous zone concluded with a small burning that is indicated by charred broad-leaved pondweed (Potamogeton natans) and curlytop knotweed (Polygonum lapathifolium) seeds and high concentration of ash. The fire intensity could be low since the seeds were only charred and the fire did not cause hiatus that can be seen from the radiocarbon ages. After that the water level increased and different mud dwelling organism settled on the mud and on the peat surface such as brown flatsedge (Cyperus fuscus), great yellowcress (Rorippa amphibia), spotted ladysthumb (Polygonum persicaria), curlytop knotweed (Polygonum lapathifolium) and cursed buttercup (Ranunculus sceleratus). In the transitional shallow lake broad-leaved pondweed (Potamogeton natans) lived. After that as a consequence of the absence of mud dwelling species, reeds (Phragmites) became more closed. So at the end of the Middle ages, beginning of the modern times, called the Ottoman occupation of Hungary in the Hungarian archaeological periodisation, the evolvement of a closed reed bog and the spread of willow-swamp (Calamagrostio-Salicetum cinereae) characterised the area.

BTM-6 (20 - $0 \mathrm{~cm})$ :

During the last 300 years reed (Phragmites), bulrush (Typha latifolia), willow (Salix), rush (Schoenoplectus) and sedge (Carex) remains accumulated.

\subsection{Pollen Analysis}

Pollen analysis was carried out in more steps. In 2007 Imola Juhász performed pollen analysis in $16 \mathrm{~cm}$ intervals [58], after that a palynological team independently analyzed the samples in $4 \mathrm{~cm}$ intervals. During pollen analysis 
69 pollen taxa were identified. The dominance of the most important and most frequent taxa and the pollen zones (BTP) obtained from the statistical analysis are presented (Figure 7).

BTP-1 (260 - $130 \mathrm{~cm})$ and BTP-2 (130 - $108 \mathrm{~cm})$ :

At the end of the Pleistocene arboreal taxa, above all pines dominate (60\% - 85\%). On the basis of the percentage value pines trees were clearly dominant around the sedimentary basin. The low, but continuous presence of Quercus, Ulmus, Carpinus, Betula and Alnus pollen a mixed taiga forest surrounded the basin. The taiga was closed and it is possible that the taiga forest lived on the wet surface of the basin.

The taiga forest was replaced then by a shallow hummock-hollow complex with sedge (Carex) and water-lily (Nymphaea alba). The ratio of grass and goosefoot (Chenopodaceae) covered areas was minimal compared to other sites in the Carpathian Basin at the end of the Pleistocene On the basis of pollen composition large grassy areas were not present in the study area. Thus, the development of vegetation in the analyzed site widely differs from the greater part of other Hungarian pollen profiles.

BTP-3 (from $108 \mathrm{~cm}$ towards the surface):

In contradiction to the statements of Juhász [58] we could separate one pollen zone in the Holocene phase of the profile, although this zone is not homogeneous and can be divided into subzones based on small changes. The evolvement of these subzones, their pollen composition, the presence or absence of the different taxa show significant difference compared to the study of Juhász [58].

BTP-3a subzone (108 - $92 \mathrm{~cm})$ :

Arboreal species dominate (above 80\%), the ratio of thermophillous species such as Tilia, Ulmus, Quercus and Corylus is secondary in the pollen material. The amount of Fagus, Betula and Alnus is significant in this horizon. Based on the radiocarbon ages this horizon corresponds to the Middle Iron Age, between the 9th and 3rd century BC [5]. On the basis of archaeological and historical sources the Hallstadt culture, after that Pannonian and Celtic communities were present in the study area in this period of time. A relatively humid and cold climate phase can be reconstructed in this phase. Probably the Oceanic climate impact could be more intense in this period, the differences between the summer and winter temperatures declined, the amount of heat of the vegetation period and the fluctuation of temperature decreased. Cereal pollen already appeared in this subzone.

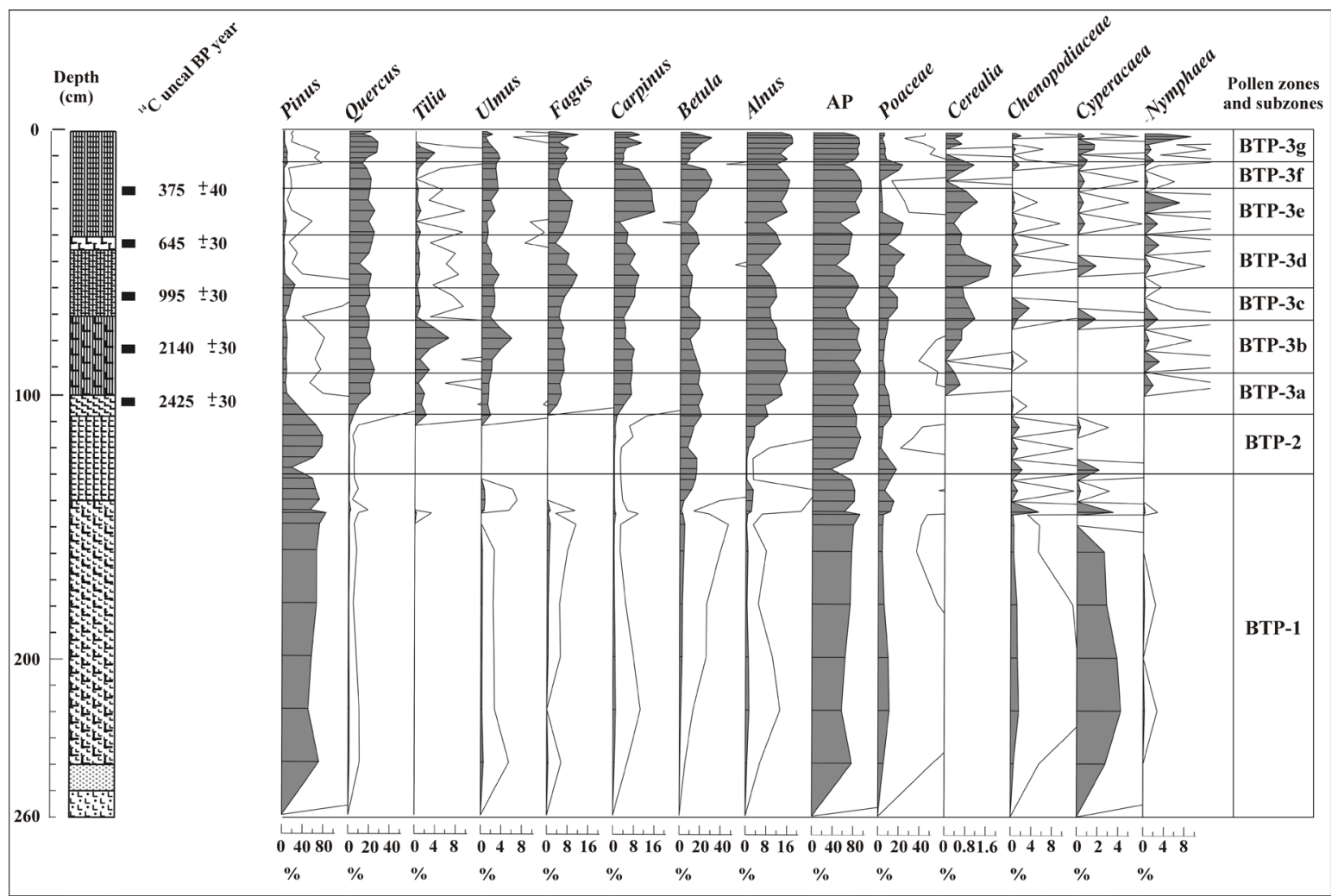

Figure 7. Percentage pollen and spore diagram of selected taxa from the analysed core sequence of Lake Baláta. 
BTP-3b subzone $(92-72 \mathrm{~cm})$ :

Arboreal species still dominate (above 80\%). Tilia, Ulmus, Quercus and Corylus emerge while the ratio of Fagus, Carpinus, Betula and Alnus decrease. Based on radiocarbon ages the horizon corresponds to the time period between the 2nd B.C. and 5th AD centuries that cover the Late Iron Age and Imperial period in the Carpathian Basin [5].

In this time span Pannonian, Celtic, Roman and romanizated communities lived in the study area. On the basis of the pollen assemblage a relatively smooth and a possibly drier climatic phase can be reconstructed. Probably the sub-Mediterranean climatic impact that is characteristic in the study area nowadays as well, amplified and combined with the continental climatic impact. Parallel to it, the impact of the oceanic climate decreased. As a result, a climatic phase with mild and dry vegetation periods can be reconstructed. Pollen of weeds and cereal indicate plant cultivation but of secondary importance because the pollen material of arboreal taxa with more than $80 \%$ point to deciduous forest in the surrounding area. Considering the size of the sedimentary basin the deciduous forest may covered a $10 \mathrm{~km}^{2}$ area.

BTP-3c subzone $(72-60 \mathrm{~cm})$ :

The ratio of arboreal species decreased (below 60\%) but still predominated. Species indicating mild climate such as Tilia, Ulmus, Quercus and Corylus decline while the ratio of Betula increase significantly. Based on radiocarbon dates between the time period of the 3rd and 10th AD centuries the horizon corresponds to the Migration period [5].

In this time horizon romanizated population, after that the presence of Germanic tribes, Avar and Frankish communities are probable based on historical sources. The pollen assemblage indicates forest destruction, while on the cleared woodland Betula trees spread. This assumption is affirmed by the presence of goosefoot (Chenopodaceae) and sedge (Carex) and the formation of open areas and meadows. Furthermore, these cut-over areas were used for animal husbandry, as grasslands and hayfields. However, the slight increase of cereal pollen grains indicate that plant cultivation became stronger. Climatological conditions can be reconstructed by the increase of the ratio of water lily (Nymphaea) that favors aquatic environment. Based on it a wetter period can be reconstructed for the Migration period and a reforestation process observable at the end of the the Migration period (8th-10th centuries). Thus, a growing cycle with more precipitation can be reconstructed. At the same time the increase of the ratio of weeds, sedge, and cereal pollen indicate that plant cultivation, but above all animal husbandry became vigorous in the study area. The ratio of arboreal pollen decreased significantly (from $80 \%$ to $60 \%)$. At the end of the Migration period in the 9th century arboreal pollen increased again above $80 \%$.

BTP-3d subzone $(60-40 \mathrm{~cm})$ :

The most intensive human impact evolved after the conquest of Hungary (Arpadian Age from the 9th century to the beginning of the14th century), after the 9th century on the basis of radiocarbon ages. Arboreal pollen decreased below 40\% - 50\% for centuries (between the 11th and 15th century). Cereal pollen reaches its maximum value, pollen of weeds, sedge (Carex), reed (Phragmites) and bulrush (Typha) increased as well. The lacustrine environment became a marshy lake and active peat formation was characteristic during the Arpadian Age. It is probable that forest disturbance and as a consequence the intensive soil erosion had a major role in the development of the marshy lake and peat formation.

BTP-3e subzone (40 - $22 \mathrm{~cm})$ :

The pollen assemblage changed significantly from the 15th century. Pollen of cereal, weeds and other plants indicating attenuated human activity and the ratio of arboreal pollen increased above $80 \%$. The ratio of Alnus, Betula, Fagus and Carpinus are rising. So a colder and wetter climatic phase can be drawn between the 15 th and 18th century.

BTP-3f subzone $(22-12 \mathrm{~cm})$ :

The subzone corresponds to the 18th century on the basis of sedimentation rate and the depth-age model. At the beginning of the subzone a burning level can be seen between 22 and $20 \mathrm{~cm}$ with the incensement and dominance of cereals and weeds indicating grasslands and treading. Probably on the cleared areas the heliophillous Corylus, Tilia and Alnus spread. The study area was under strong human impact.

BTP-3g subzone (from $12 \mathrm{~cm}$ towards the surface):

From the beginning of the 19th century, a Quercus-Betula-Carpinus-Fagus dominated forest evolved in the area, with Tilia and Ulmus. Ratio of arboreal pollen grains exceeded 90\%. The pollen assemblage indicates that a colder, wetter period developed in the 19th century. During the 20th century the ratio of Alnus decreased, Quercus, Ulmus, Carpinus and Fagus spread. 


\subsection{Charcoal Analysis}

We present the results of charcoal analyses from the Late Iron Age. The total number of the analysed charcoal fragments is 2500. The number of anthracological samples collected from Early Iron Age archaeological features is very low (Table 4). Only a few pieces of Quercus, Prunus, Fraxinus, Acer, Salix/Populus and Juniperus were found. Charcoal samples from Late-Iron Age features indicate Quercus dominance; besides Alnus and Fraxinus fragments represent the charcoal assemblage.

Only low amount of charcoal fragments were found from the objects of the Imperial period but they show heterogeneity. Pinus, Fagus, Fraxinus, Quercus, Ulmus, Acer and Alnus remains were found. Fraxinus dominance can be reconstructed during the migration period. Quercus is also present, in addition Fagus, Salix/Populus, Acer, Alnus and Ulmus. The archaeological features of the Arpadian age signify Quercus dominance, over and above Ulmus, Alnus, Acer, Fraxinus, Fagus, Prunus, Salix/Populus, Corylus and Juniperus. Charcoal material of middle ages is very similar to the charred wood samples of the Arpadian age with Quercus prevalence and edge vegetation indicator species.

\section{Discussion}

On the basis of sedimentological, geochemical, macrobotanical and pollen analysis we could reconstruct the system of Lake Baláta. Environment historical analysis indicates two different palaeoecological states in the sedimentary basin.

\subsection{Pleistocene Environment}

The section between 260 and $108 \mathrm{~cm}$ probably evolved at the end of the Pleistocene, during the Late Glacial between 18 and 12 thousand yr cal BP on the basis of sedimentation and pollen data (Figure 8). The pollen material is well preserved. Arboreal pollen, above all pines dominate with $60 \%-85 \%$. Based on this taiga forest existed in the deepest part of the basin. The presence of broad-leaved and narrow-leaved deciduous trees, such as Quercus, Ulmus, Fagus, Carpinus, Betula and Alnus pollen indicate that mixed taiga forest surrounded and covered the basin.

\subsection{Late Holocene Environment}

The lacustrine environment developed at the beginning of the 1st millennia $\mathrm{BC}$ is problematic, as well as the

Table 4. Summary of fragment counts of charcoal fragments.

\begin{tabular}{|c|c|c|c|c|c|c|}
\hline Charcoal taxa & $\begin{array}{c}\text { Early Iron age } \\
(900 / 800-700 \mathrm{BC})\end{array}$ & $\begin{array}{l}\text { Late Iron age } \\
\text { (450 BC-AD) }\end{array}$ & $\begin{array}{l}\text { Imperial period } \\
\text { (40 BC-422 AD) }\end{array}$ & $\begin{array}{l}\text { Migration period } \\
\text { (400-895 AD) }\end{array}$ & $\begin{array}{c}\text { Arpadian age and Middle ages } \\
(1000-1526 \mathrm{AD})\end{array}$ & $\begin{array}{l}\text { total } \\
\text { number }\end{array}$ \\
\hline Acer & 1 & & 1 & 2 & 10 & 14 \\
\hline Alnus & - & 23 & 1 & 1 & 14 & 39 \\
\hline Carpinus & - & - & - & - & 1 & 1 \\
\hline Corylus & - & - & - & - & 2 & 2 \\
\hline Fagus & - & - & 7 & 51 & 5 & 63 \\
\hline Fraxinus & 1 & 23 & 6 & 1203 & 8 & 1241 \\
\hline Juniperus & 1 & - & - & - & 1 & 2 \\
\hline Pinus & - & - & 8 & - & - & 8 \\
\hline Populus/Salix & 1 & - & - & 5 & 2 & 8 \\
\hline Prunus & 2 & - & - & - & 6 & 8 \\
\hline Quercus & 11 & 221 & 4 & 351 & 498 & 1085 \\
\hline Ulmus & - & - & 1 & 1 & 27 & 29 \\
\hline $\begin{array}{l}\text { Number of identified } \\
\text { fragments }\end{array}$ & 17 & 267 & 28 & 1614 & 574 & 2500 \\
\hline
\end{tabular}




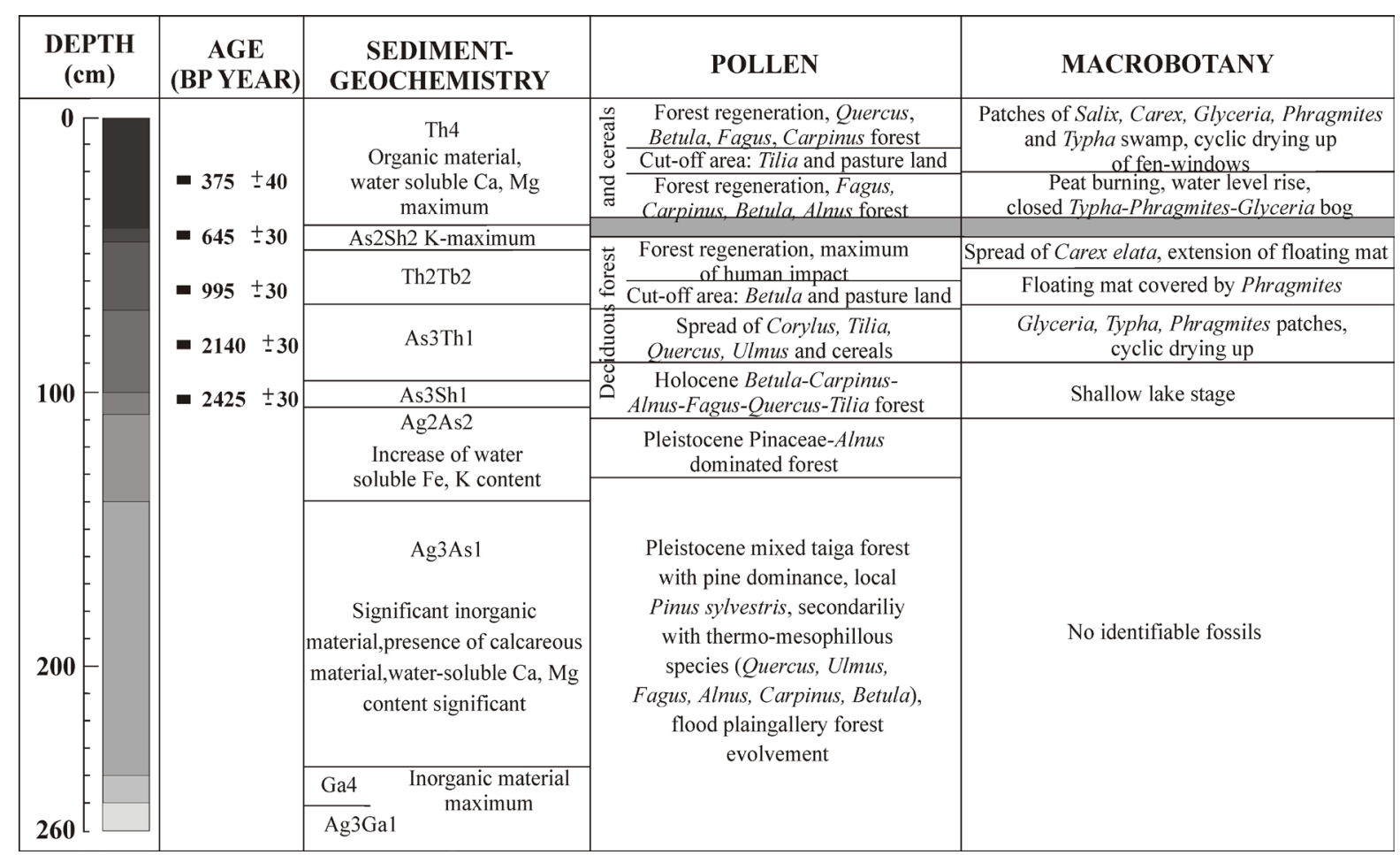

Figure 8. Description of geochemical, molluscan and pollen zones of Lake Baláta sedimentary sequence.

supposed desiccation of the basin at the end of the Pleistocene. We could not reveal lake or marshy sediments accumulated during the Early Holocene in none of the 20 cores, neither at the north nor at the south part of the basin. At the same time eutotrophic and marshy lake sediments that accumulated during the Late Holocene were found in almost all parts of the basin.

\subsection{Early and Middle Iron Age}

Lake and marshy lake sediments started to accumulate during the 1st millennia BC, during the Early Iron Age (Figure 9). On the basis of geochemical and sedimentological parameters shallow lake conditions developed during this period of time. The 2 meter deep, clear and open surface of the lake basin was surrounded by Betula-Carpinus-Alnus-Fagus dominated forest; however pollen of cereals were relatively significant as well. The dissolved iron, potassium and sodium content of the lake are high and rich in organic material; so the lake could be mesotrophic. The pollen composition indicate that the lake-shore was covered by reed (Phragmites) and bulrush (Typha); at some places it appeared mixed with floating and rooted reed-grass associations such as Nymphaea alba, Myriophyllum and Nuphar lutea.

This stage of the lake during the Early Iron Age can be well synchronized with the global climatic trend of this time period, i.e. with the colder, wetter horizons reconstructed from ice sheet analysis, with the rise of lake water levels in Switzerland [59] and with the expansion of glaciers in the Alps [60]. At the same time, it is unambiguous that our proxy data do not reflect such high degree water level changes in Lake Baláta during the Early Iron Age that is observable in case of the Swiss lakes (Figure 10).

This phase of the lake environment subsisted until to the second half of the Imperial period, after the 3rd century AD. Based on our results the Early Iron Age Hallstadt culture settled down in a relatively colder and wetter climatic phase in the study area. Despite of that, only a few charcoal pieces were found from this period of time. A higher precipitation input characterized the time period of the settling down of the Pannonian and Celtic populations as well, but the temperature changed significantly.

\subsection{Late Iron Age}

Due to the eutrophication of the lake narrow-leaved bulrush (Typha latifolia) and floating mat with sweet-grass 


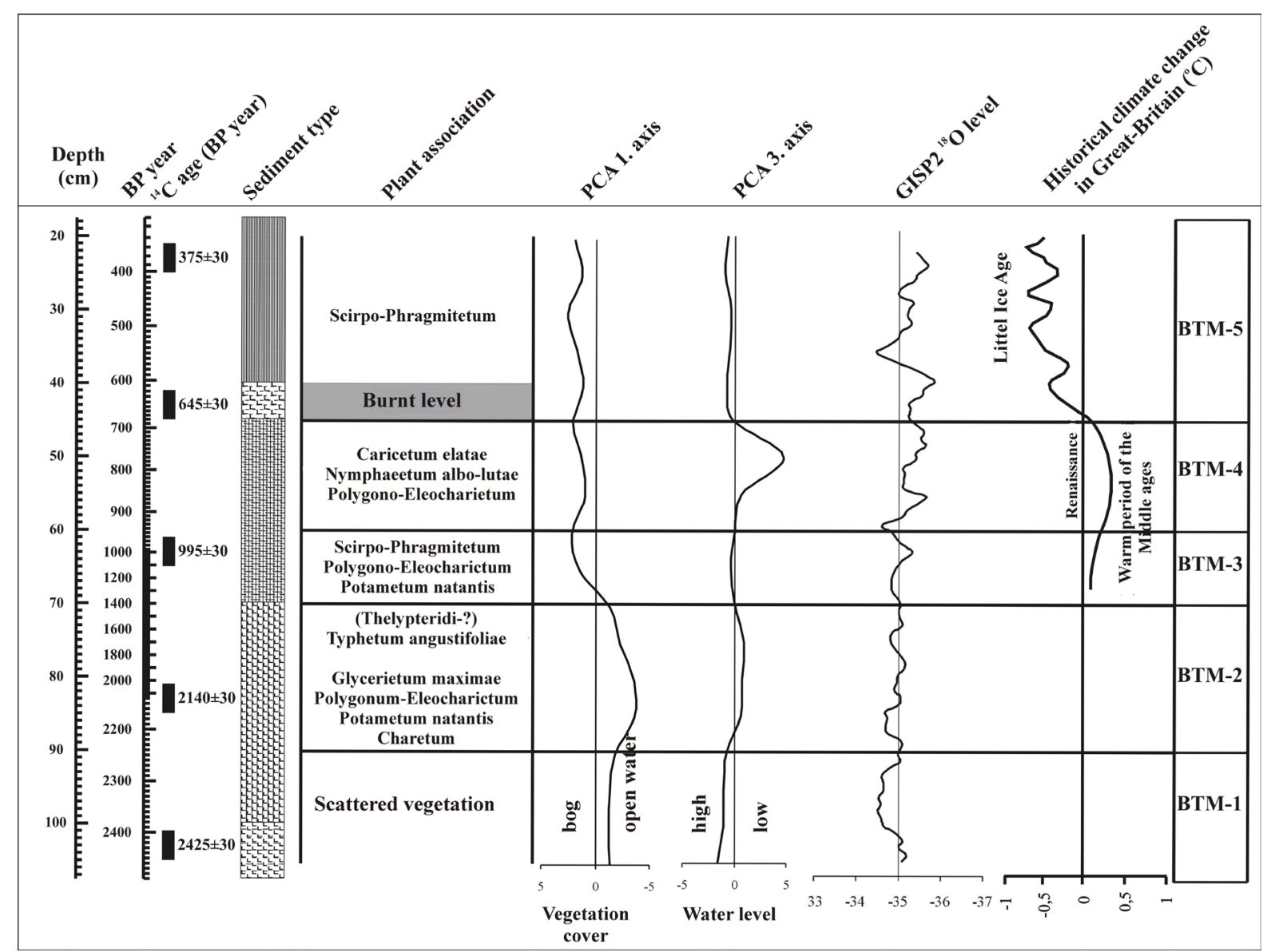

Figure 9. Plant association and water level changes during the last 3000 years based on macrobotanical data.

(Glyceria) appeared at the south part of the lake as a result of currents created by the north wind, so an increasing marshy zone developed in the lake basin. By the evolvement of the marshy zone around the lake, reed and sedge associations spread and divided the open surface of the lake. Probably the mosaic-like vegetation stage developed during this period of time. Vegetation change from the 3rd century BC was climatic and succession induced spatial displacements. On the basis of pollen data a smooth climatic phase can be reconstructed from the 3rd century BC to the 3rd century AD Tilia-Ulmus-Quercus-Corylus dominated forest evolved around Lake Baláta and the amount of precipitation was still higher at the end of the Iron Age. Charcoal assemblage indicates Quercus dominance, besides Fraxinus and Alnus occurred. Tilia and Corylus are missing that probably suggest that the wood of Tilia was not utilized for burning and construction activity. So it is necessary to eliminate the selection of wood. Quercus and Fraxinus can be used as firewood due to their good heating power [64]. In contradiction, Tilia is unsuitable for firewood (Kreuz, 1992). So it may be a reason for its missing in the charcoal assemblage here and in the case of other archaeological sites as well [65] [66].

The mild climate is well synchronized with the oxygen isotope changes of ice sheet [67] [68] analysis, with the water level drop of Swiss lakes [69] and with the retreat of glaciers in the Alps [60]. The annual temperature was higher than that of today, $9.8^{\circ} \mathrm{C}$ based on pollen analysis. Parallel to it the amount of precipitation decreased.

\subsection{Imperial Period}

From the end of the Imperial period and during the migration period the sweet-grass-bulrush-reed covered the surface of Lake Baláta. The development of a closed peat bog can be explained by succession processes, but it is outstanding that at the beginning of the Imperial period the sedimentary basin was surrounded by a Tilia-UlmusCorylus and Quercus dominated forest. At the same time, between the 3rd and 5th century, at the beginning 


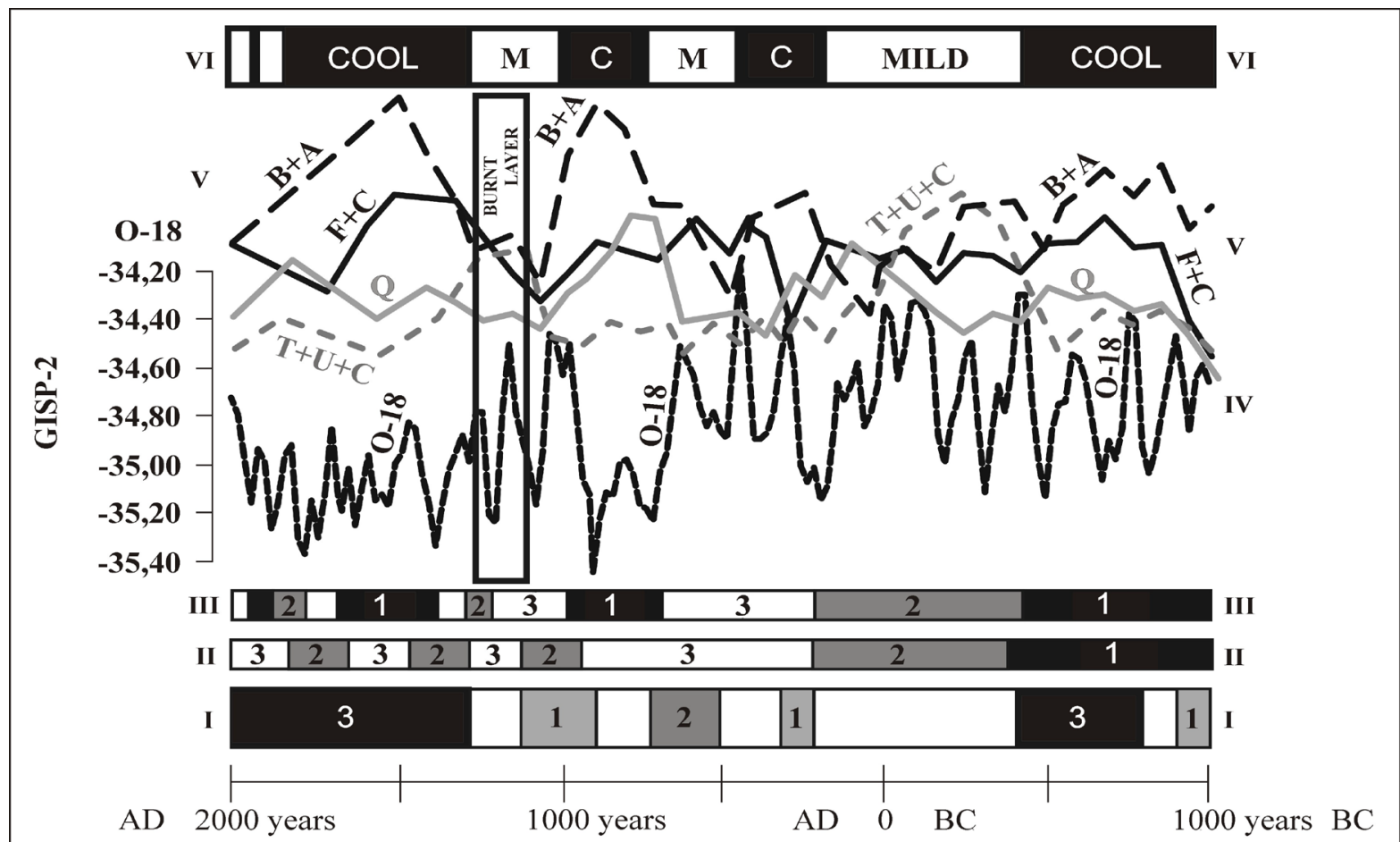

I Swiss lake level changes (based on Magny's papers): $1=$ one meter increasing lake level; $2=$ two meters increasing lake level; $3=$ three meters increasing lake level; white parts= lake level decreasing

II Lake level changes of Lake Baláta based on macrobotanical remains: 1= Open water surface, $2=$ Floating mat stage, $3=$ Peatland stage

III Terrestrial vegetation change based on pollen data: $1=$ Fagus-Carpinus-Alnus-Betula forest dominance phase; $2=$ Tilia-Ulmus-Corylus-Quercus forest dominance phase

IV Oxygene isotope change in the GISP 2 core sequence during last 3000 years

$\mathrm{V}$ Pollen content dominance change: $\mathrm{B}+\mathrm{A}=$ Betula and Alnus, $\mathrm{F}+\mathrm{C}=$ Fagus and Carpinus, $\mathrm{Q}=$ Quercus, $\mathrm{T}+\mathrm{U}+\mathrm{C}=$ Tilia, Ulmus, Corylus

VI Pollen-based climatic reconstruction of the analysed sequence in Lake Baláta

(based on Davis et al. 2001, 2003; Magyari 2002)

Figure 10. Environmental historical data changes in the basin of Lake Baláta and its environment during the last 3000 years [61]-[63].

of the formation of the marshy lake, the ratio of arboreal pollen decreased drastically. A little amount of charcoals were found in the archaeological sites. Among that Pinus occurred, that may indicate its slight spread on the cut-off areas. The presence of Fagus is not due to climate change rather it indicates anthropogenic effect. Namely, the beginning of the spread of floating mat and the drop of arboreal pollen clearly correlates and based on this we assume that due to deforestation soil erosion and the eutrophication of the lake became stronger. This process was promoted by the decrease of precipitation at the beginning of the Imperial period compared to the Early Iron Age precipitation maximum. After deforestation the ratio of cereal pollen increase, but on the basis of the growth of its ratio we cannot suppose that it was grown in the vicinity of the bog, rather it indicates regional origin. At the same time pollen weeds typical for grasslands and the pollen ratio of pungent and poisonous plants did not increase after forest clearance. So the purpose of deforestation is may be wood cutting that was not followed by plant cultivation or grazing in the close vicinity of the bog during the Imperial period. At the beginning of the Migration period trampling tolerant weeds (Chenopodiaceae) appear that indicate that land use changed from the 5th-6th centuries AD.

\subsection{Migration Period}

The closed reed-bulrush-sedge vegetation still existed in the basin of Lake Baláta. An open, grass covered area surrounded the bog and the pollen ratio of arboreal species was the lowest in the profile in this level, despite that a wetter and colder climatic phase developed. Among arboreal species the pollen amount of Betula and Alnus 
that spread easily on cleared surfaces is noteworthy, so we can assume that a significant grassland and stockbreeder zone were created in the milieu of the bog. This animal keeping zone was later utilized by Germanic and Avar populations as well. This kind of land use came to an end in the 8th century AD and fast forest regeneration evolved. Fagus-Carpinus-Alnus and Betula trees dominated in the forest assemblage at the end of this period of time. Charred wood remains indicate Fraxinus dominance. Almost 75\% of charcoal belongs to the genus that derives from this time period. This raises more questions, such as was Fraxinus dominant in the forest more than Quercus? Or the high amount of Fraxinus is caused by the fragmentation of samples, or the selection of wood as it has good heating power? The climate for this time period reconstructed from macrobotanical and pollen analysis indicate that a colder and wetter climatic phase developed. Since Fraxinus is thermophillous and high amount of Fraxinus occurred from one object (more than 1000 pieces) it is obvious that the sample fragmentized and this caused the high fragment number of the genus. Thus Fraxinus was probably selected but not dominant in the forest assemblage.

At the end of the period due to the increase of precipitation the bog broke out and a boggy lake environment developed with floating mat with bulrush (Typha latifolia) and water-lily (Nymphaea alba) patches.

\subsection{Arpadian Age and Middle Ages}

During the Arpadian Age a cut-off area was created around the bog between the 11th and 13th centuries and extent plant cultivation and grazing field zones were worked up. Parallel to the significant forest destruction the boggy lake that evolved before the Arpadian Age transformed and a close, bog developed covered by reeds with broad-leaved pondweed (Potamogeton natans) and tussock sedge (Carex elata). The creation of the agricultural area happened in a mild and dry climatic phase. These data indicate the rise of the continental and the dry mediterranean climatic effect in the study area.

The charcoal material indicates Quercus dominance; in addition Ulmus, Alnus, Acer, Fagus, Fraxinus and Prunus and Carpinus occurred. The few pieces of Corylus and Juniperus indicate edge vegetation owing to the fact that they are light demanding species. The presence of thermophillous and heliophyte plant types such as Quercus, Acer, Ulmus, Fraxinus and Prunus correlates well with the drier climate and their ratio with the result of pollen analysis, that is Quercus and Ulmus were the dominant tree in the forest assemblage. The diversity of charcoal material compared to the previous time periods might strengthen the forest destruction activity. Namely, all of the felled woods were utilized as firewood, however, Quercus and Ulmus were probably selected as well as these types of wood are the best for construction purposes [58].

In the 13th century AD the bog dried up and burnt down. The cause of the drying up of the bog is the repetition of dry-sub-Mediterranean years, the increase of the continental effect that is observable nowadays as well and the combination of the two climatic effects. This time period is the "Viking climatic optimum" (between 1000-1300 AD) [70] when the climate of Europe became warmer. The global trend of this warmer period is proved by the oxygen isotopic analysis of ice cores in Greenland [71]. Since similar trends were observable in the Late Iron Age and at the beginning of the Imperial period, it is probable that similar climatic influence developed in the "Roman optimum" as well. At the same time these mild and dry phases correlate well with the global warming up phases if we take into consideration the aspects of a question regarding the sedimentation rate and the chronological correlation of the climatic phases [72]. However, on the basis of proxy data there are significant deviations relating to the climatic development of the Carpathian Basin and the palaeoecological evolvement of Lake Baláta compared to West- and North-European areas.

After the 13th century a boggy lake environment evolved, later a closed, tussock sedge (Carex elata) and reed (Phragmites) dominated bog developed in the second part of the 15th century. Parallel to this human impact decreased in the study area that indicates the reduction of the population and agrarian activity. The depopulation process and the decrease of economic activity started before the Ottoman occupation of Hungary in the 16th century and it is not the consequence of the conquering Ottoman campaign.

\subsection{Ottoman Occupation of Hungary}

In the 16th century the environment of the lake transformed. Human impact decreased and in a cold-wet climatic phase a closed Fagus-Carpinus-Alnus-Betula dominated forest developed around the deeper flatted area. Due to the significant amount of precipitation the bog reopened and a boggy lake stage formed. This is related to the colder and moist climatic phase of the Little Ice Age. The spatial extension of Phragmites, Typha latifolia, 
Carex elata and floating mat covered areas changed depending on the fluctuation of precipitation until to the river and groundwater controls of the 20th century. From this time anthropogenic impact is determinant in the development of the bog.

\subsection{Modern Ages}

The boggy lake with different bog and open water surface ratio remained during the modern ages as well. In the 18th century a significant warming up started and the annual temperature increased by $0.5^{\circ} \mathrm{C}$ in 100 years and exceeded $10^{\circ} \mathrm{C}$ for $30-50$ years on the basis of proxy data. During the 18th century forest destruction started in the vicinity if lake Baláta, and besides the results of pollen analysis recorded sources support this activity [73] [74]. After deforestation Tilia-Ulmus-Corylus dominated forest developed under mild and drier climatic conditions. But it is not clear if the forest covered the cut-off areas or developed due to climatic change. In the second part of the 18th century arboreal pollen was higher than $90 \%$ and it is a significant rise compared to its ratio of $50 \%$ that was characteristic during the first part of the 18th century. At the beginning of the 19th century Quercus-Carpinus-Alnus-Betula-Fagus dominated forest developed in which the ratio of Quercus became more characteristic in the 20th century.

\section{Conclusions}

Complex environment historical analysis including sedimentological geochemical, macrobotanical, pollen and anthracological analysis was obtained for the last 3000 years in Southwestern Hungary. The results show that shallow lake conditions developed during the Early Iron Age. The clear and open surface of the mesotrophic lake was surrounded by Betula-Carpinus-Alnus-Fagus dominated forest and pollen of cereals were significant as well. The lake-shore was covered by Phragmites and Typha latifolia; at some places it appeared mixed with floating and rooted reed-grass associations. This phase of the lake environment subsisted until to the second half of the Imperial period, after the 3rd century AD. This environment developed in a colder and wetter climatic phase. During the Late Iron Age an increasing marshy zone developed where reedy and sedge associations spread and divided the open surface of the lake. On the basis of pollen data a smooth climatic phase can be reconstructed from the 3rd century BC to the 3rd century AD when Tilia-Ulmus-Quercus-Corylus dominated forest evolved and the amount of precipitation was higher.

At the beginning of the Imperial period the sedimentary basin was surrounded by a Tilia-Ulmus-Corylus and Quercus dominated forest; however the ratio of arboreal pollen decreased drastically. Pinus charcoals turned up from this time period that might indicate its spread on the cut-off areas. Due to forest destruction, soil erosion and the eutrophication of the lake became stronger, and the area of bog increased. The ratio of cereals increased, but it indicates regional origin based on the growth of its ratio.

At the beginning of the Migration period the closed Phragmites-Typha-Carex covered bog still existed in the basin of Lake Baláta. An open, grass covered area surrounded the bog and the pollen ratio of arboreal species was the lowest in the profile, despite the wetter and colder climate. Pollen data indicate that a significant grassland and stock-breeder zone were created in the milieu of the bog. This kind of land use ended in the 8th century $\mathrm{AD}$ and fast forest regeneration started. Fagus-Carpinus-Alnus and Betula trees dominated in the forest assemblage at the end of this period of time due to the increasing precipitation.

During the Arpadian Age the climate became mild and dry. Cleared areas were created around the bog between the 11th and 13th centuries and extent plant cultivation and grazing field zones were created. The bog closed, and was covered by Potamogeton natans and Carex elata. Charcoal assemblage indicates Quercus dominance with Ulmus, Acer, Fraxinus and Prunus that correlate well with the drier climate and their ratio with the result of pollen analysis, namely that Quercus and Ulmus were the dominant trees in the forest assemblage. The diversity of charcoal taxa compared to the previous time periods indicates that felled wood of different taxa is utilized as firewood; however Quercus and Ulmus were probably selected for construction purposes (Juhász, 2007) as well.

During the "Viking climatic optimum" (between 1000-1300 AD) [70] the bog burnt down due to the repetition of dry-sub-Mediterranean years. After that a boggy lake environment evolved, that was followed by the development of a closed Carex elata and Phragmites dominated bog in the second part of the 15th century. In the 16th century the area depopulated and human activity decreased. During the Little Ice Age, due to the cold and wet climatic phase, a closed Fagus-Carpinus-Alnus-Betula dominated forest developed around the sedimentary 
basin. At the same time the bog reopened and a boggy lake evolved with different bog-open water surface ratios. In the 18th century warming up started and the annual temperature increased by $0.5^{\circ} \mathrm{C}$ in 100 years. Due to the drier climatic conditions and forest destruction in the first part of the 18th century a Tilia-Ulmus-Corylus dominated forest evolved. At the end of this century reforestation started and at the beginning of the 19th century a Quercus-Carpinus-Alnus-Betula-Fagus dominated forest developed.

\section{Acknowledgements}

This study was carried out through project TÁMOP-4.1.1 C-12/1/ KONV-2012-0012. Pál Sümegi’s research was supported by the European Union and the State of Hungary, co-financed by the European Social Fund in the framework of TÁMOP-4.2.4.A/ 2-11/1-2012-0001 "National Excellence Program”.

\section{References}

[1] Willis, K.J., Sümegi, P., Braun, M. and Tóth, A. (1995) The Late Quaternary Environmental History of Bátorliget, N.E. Hungary. Palaeogeography, Palaeoclimatology, Palaeoecology, 118, 25-47. http://dx.doi.org/10.1016/0031-0182(95)00004-6

[2] Willis, K.J., Sümegi, P., Braun, M., Bennett, K.D. and Tóth, A. (1998) Prehistoric Land Degradation in Hungary: Who, How and Why? Antiquity, 72, 101-113.

[3] Magyari, E., Sümegi, P., Braun, M., Jakab, G. and Molnár, M. (2001) Retarded Wetland Succession: Anthropogenic and Climatic Signals in a Holocene Peat Bog Profile from North-East Hungary. Journal of Ecology, 89, 1019-1032. http://dx.doi.org/10.1111/j.1365-2745.2001.00624.X

[4] Magyari, E.K., Buczkó, K., Jakab, G., Braun, M., Pál, Z. and Karátson, D. (2009) Palaeolimnology of the Last Eastern Carpathian Crater Lake: A Multiproxy Study of Holocene Hydrological Changes. Hydrobiology, 631, 29-63. http://dx.doi.org/10.1007/s10750-009-9801-1

[5] Vaday, A. (2004) Chronological Charts. In: Visy, Zs., Ed., Hungarian Archaeology in the Turn of the Millennium, Ministry of National Cultural Heritage, Teleki László Foundation, Budapest, 473-477.

[6] Borhidi, A. and Járai-Komlódi, M. (1959) Die Vegetation des Naturschutzgebietes des Baláta Sees (Vegetation of the Reserve Area of Lake Baláta). Acta Botaniqua Academia Science Hungarica, 5, 259-320.

[7] Borhidi, A. and Járai-Komlódi, M. (1959) A csapadék-és vízszint-ingadozás összefüggése a Baláta-tó természetvédelmi területén (Rainfall and water level fluctuation correlation in Nature Reserve area of Lake Baláta). Időjárás, 63, 225-229.

[8] Borhidi, A. (1968) Dynamical Changes of Free Floating Water-Plant Communities of Different N-Sources in the Nature Reservation Area of Baláta-Pond. Acta Biologica Hungarica, 19, 19.

[9] Borhidi, A. and Járai-Komlódi M. (1960) A Baláta-tó növényvilága (Flora of Lake Baláta). Természettudományi Közlöny, 91, 501-503.

[10] Marosi, S. (1970) Belső-Somogy kialakulása és felszínalaktana (Evolution and Geomorphology of Belső-Somogy). Akadémiai Kiadó, Budapest.

[11] Marián, M. (1957) A Baláta gerinces állatvilága (Vertebrata fauna of Lake Baláta). Somogyi Almanach I., Kaposvár.

[12] Kasza, F. and Marián, M. (2001) A Baláta láp és gerinces állatvilága, különös tekintettel a madarakra (Vertebrata Fauna of Lake Baláta, Especially Birds). Natura Somogyensis 2, Kaposvár.

[13] P. Barna, J. (2007) Középső és késői újkőkor átmenete: Sopot kultúra. Sormás-Mántai-dűlő és Sormás-Török-földek (Middle and Late Neolithic Transition: Sopot Culture. Sormás-Mántai-dülő and Sormás-Török-földek Site. In: Ilon, G., Ed., Wonderful Beauties-Human Representations in Prehistoric Western Hungary, Vas Megyei Múzeumok Igazgatósága, Szombathely, 84-99.

[14] Jowsey, P.C. (1966) An Improved Peat Sampler. New Phytologist, 65, 245-248. http://dx.doi.org/10.1111/j.1469-8137.1966.tb06356.x

[15] Aaby, B. and Digerfeldt, G. (1986) Sampling Techniques for Lakes and Bogs. In: Berglund, B.E., Ed., Handbook for Holocene Palaeoecology and Palaeohydrology, John Wiley and Sons Ltd., Chichester, 181-194.

[16] Bennett, K.D. (1992) Psimpoll—A Quickbasic Program That Generates Postscript Page Description of Pollen Diagrams. INQUA Commission for the Study of the Holocene: Working Group on Data-Handling Methods, Newsletter 8, $11-12$.

[17] Troels-Smith, J. (1955) Karakterisering af lose jordater (Characterisation of Unconsolidated Sediments). Danmarks Geologiske Undersogelse, 3, 39-73. 
[18] Dean, W.E. (1974) Determination of Carbonate and Organic Matter in Calcareous Sediments and Sedimentary Rocks by Loss on Ignition: Comparison with Other Methods. Journal of Sedimentology Research, 44, 242-248.

[19] Dániel, P., Kovács, B., Győri, Z. and Sümegi, P. (1996) New Complex Geochemical Investigation Method for Lake Sediments. Abstracts of 4th Soil and Sediment Contaminant Analysis Workshop, Lausanne.

[20] Dániel, P. (2004) Geochemical Analysis. In: Sümegi, P. and Gulyás, S., Eds., The Geohistory of Bátorliget Marshland, Archaeolingua Press, Budapest, 52-57.

[21] Sümegi, P. (1999) Reconstruction of Flora, Soil and Landscape Evolution, and Human Impact on the Bereg Plain from Late-Glacial up to the Present, Based on Palaeoecological Analysis. In: Hamar, J. and Sárkány-Kiss, A., Eds., The Upper Tisa Valley, Tiscia Monograph Series, Szeged, 173-204.

[22] Rollinson, H. (1993) Using Geochemical Data: Evaluation, Presentation and Interpretation. Longman, London, Essex.

[23] Dowdeswell, J.A. (1982) Relative Dating of Late Quaternary Deposits Using Cluster and Discriminant Analysis, Audubon Cirque, Mt. Audubon, Colorado Front Range. Boreas, 11, 151-161. http://dx.doi.org/10.1111/j.1502-3885.1982.tb00532.x

[24] Barber, K.E., Chambers, F.M., Maddy, D. and Brew, J. (1994) A Sensitive High Resolution Record of the Holocene Climatic Change from a Raised Bog in Northern England. Holocene, 4, 198-205. http://dx.doi.org/10.1177/095968369400400209

[25] Jakab, G., Sümegi, P. and Magyari, E. (2004) A New Palaeobotanical Method for the Description of Late Quaternary Organic Sediments (Mire-Development Pathways and Palaeoclimatic Records from S Hungary). Acta Geologica Hungarica, 47, 373-409. http://dx.doi.org/10.1556/AGeol.47.2004.4.4

[26] Jakab, G. and Sümegi, P. (2004) A lágyszárú növények tőzegben található maradványainak határozója mikroszkópikus bélyegek alapján (Identifying of Herbaceous Plant Remains from Peat on the Basis of Microscopic Features). Kitaibelia, 9, 93-129.

[27] Juhász, I.E., Jakab, G. and Sümegi, P. (2004) Vegetation Dynamics of a Small Sphagnum Peat Bog from North Hungary, from the Late Pleistocene until Late Holocene: Palynological and Macrobotanical Data. Abstracts of the 11th International Palynological Congress, Granada, 508.

[28] Juhász, I. (2005) Preliminary Palynological Results from the Nádas-to peat bog at Nagybárkány, North-East Hungary. The Late Holocene Environmental History. In: Gál, E., Juhász, I. and Sümegi, P., Eds., Environmental Archaeology in North-Eastern Hungary, Varia Archaeologica Hungarica, Budapest, 79-85.

[29] Berglund, B.E. and Ralska-Jasiewiczowa, M. (1986) Pollen Analysis and Pollen Diagrams. In: Berglund, B.E., Ed., Handbook of Holocene Palaeoecology and Palaeohydrology, John Wiley and Sons Press, Chichester, 455-484.

[30] Stockmarr, J. (1971) Tablets with Spores Used in Absolute Pollen Analysis. Pollen et Spores, 13, 615-621.

[31] Maher Jr., L.J. (1972) Nomograms for Counting 0.95 Confidence Limits of Pollen Data. Review of Palaeobotaní and Palynology, 13, 85-93. http://dx.doi.org/10.1016/0034-6667(72)90038-3

[32] Clark, R.L. (1982) Point Count Estimation of Charcoal in Pollen Preparation and Thin Sections of Sediments. Pollen et Spores, 24, 523-535.

[33] Moore, P.D., Webb, J.A. and Collinson, M.E. (1991) Pollen Analysis. Blackwell Scientific Publications, Oxford.

[34] Beug, H.J. (2004) Leitfaden der Pollenbestimmung für Mitteleuropa und angrenzende Gebiete (Guide to the Pollen Analysis for Central Europe and the Adjacent Areas). Pfeil, München.

[35] Punt, W. (1980) Pollen Morphology of the Phyllanthus Species (Euphorbiaceae) Occuring in New Guinea. Review of Palaeobotany and Palynology, 31, 155-177. http://dx.doi.org/10.1016/0034-6667(80)90025-1

[36] Kozáková, R. and Pokorný, P. (2007) Dynamics of the Biotopes at the Edge of a Medieval Town: Pollen Analysis of Vltava River Sediments in Prague, Czech Republic. Preslia, 79, 259-281.

[37] Reille, M. (1992) Pollen et spores d'europe et d'afrique du nord (Pollen and Spores of Europe and North Africa). Laboratoire de Botanique historique et Palynologie, Marseille.

[38] Reille, M. (1995) Pollen et Spores d'Europe et d'Afrique du Nord. Supplement 1 (Pollen and Spores of Europe and North Africa, Supplement 1). Laboratoirede Botanique Historique et Palynologie, Marseille.

[39] Reille, M. (1998) Pollen et Spores d'Europe et d'Afrique du Nord. Supplement 2 (Pollen and Spores of Europe and North Africa, Supplement 2). Laboratoirede Botanique Historique et Palynologie, Marseille.

[40] Sümegi, P., Náfrádi, K. and Töröcsik, T. (2011) The Methology Employed. In: Kvassay, J., Ed., The Late Urnfield Period Cemetery from Szombathely-Zanat Supplemented by an Assessment of Prehistoric and Medieval Settlement Features and Interdisciplinary Analysses, VIA-Monographia Minor in Cultural Heritage 2, Hungarian National Museum-National Cultural Heritage Protection Centre, Budapest, 203-214.

[41] Jacomet, S. and Kreuz, A. (1999) Archäobotanik. Aufgaben, Methoden und Ergebnisse vegetations und agrargeschich- 
tlicher Forschung (Archaeobotany. Tasks, Methods and Results of Vegetation and Agro-Historical Research). Ulmer, Stuttgart.

[42] Gyulai, F. (2001) Archaeobotanika. A kultúrnövények története a Kárpát-medencében a régészeti növénytani vizsgálatok alapján (Archeobotany. History of Domesticated Plants in the Carpathian Basin on the Basis of Archaeological Plant Analyses). Jószöveg Mühely, Budapest.

[43] Chabal, L., Fabre, L., Terral, J.F. and Théry-Parisot, I. (1999) L’anthracologie (Anthracology). In: Bourquin-Mignot, C., Brochier, J.E., Chabal, L., Crozat, S., Fabre, L., Guibal, F., Marinval, P., Richard, H., Terral, J.F. and Théry, I., Eds., La Botanique, France, Paris, 43-104.

[44] Asouti, E. and Austin, P. (2005) Reconstructing Woodland Vegetation and Its Exploitation by Past Societies, Based on the Analysis and Interpretation of Archaeological Wood Charcoal Macro-Remains. Environmental Archeology, 10, 118. http://dx.doi.org/10.1179/env.2005.10.1.1

[45] Greguss, P. (1945) A középeurópai lomblevelü fák és cserjék meghatározása szövettani alapon (Identification of Deciduous Trees and Shrubs in Central Europe). Országos Magyar Természettudományi Múzeum, Budapest.

[46] Greguss, P. (1972) Xyotomy of the Living Conifers. Akadémia Kiadó, Budapest.

[47] Schweingruber, F.H. (1990) Microscopic Wood Anatomy. Eidgenössiche Forschungsantalt für Wald, Schnee und Landchaft, Birmensdorf.

[48] Reimer, P.J., Bard, E., Bayliss, A., Beck, J.W., Blackwell, P.G., Bronk-Ramsey, C., Buck, C.E., Cheng, H., Edwards, R.L., Friedrich, M., Grootes, P.M., Guilderson, T.P., Haflidason, H., Hajdas, I., Hatté, C., Heaton, T.J., Hogg, A.G., Hughen, K.A., Kaiser, K.F., Kromer, B., Manning, S.W., Niu, M., Reimer, R.W., Richards, D.A., Scott, E.M., Southon, J.R., Turney, C.S.M. and Van der Plicht, J. (2013) IntCal13 and Marine13 Radiocarbon Age Calibration Curves 0-50000 Years calBP. Radiocarbon, 55, 1869-1887. http://dx.doi.org/10.2458/azu_js_rc.55.16947

[49] Sümegi, P. (2003) Régészeti geológia és történeti ökológia alapjai (Basics of Geoarchaeology and Historical Ecology). JATE Press, Szeged.

[50] Sümegi, P. (2007) Description of the Sampling Location at Baláta-tó. In: Zatykó, Cs., Juhász, I. and Sümegi, P., Eds., Environmental Archaeology in Transdanubia (Hungary), Varia Archaeologica Hungarica, Budapest, 322-324.

[51] Balogh, M. (1983) A Velencei-tó nyugati medencéjének úszólápjai és hatásuk a tó vízminőségére (Floating Mats and Their Effect on Water Quality in the Western Side of Lake Velencei). Candidate Dissertation, MTA-VITUKI, Budapest.

[52] Balogh, M. (2000) Az úszólápi szukcesszió kérdései I. (Questions of Floating Mat Succession I.). Kitaibelia, 5, 9-16.

[53] Braun, M., Sümegi, P., Szűcs, L. and Szöőr, G. (1993) A kállósemjéni Nagy-Mohos láp fejlődéstörténete (Lápképződés emberi hatásra és az ősláp hipotézis) (Evolution of Nagy-Mohos Bog in Kállósemjén). Jósa András Múzeum Évkönyve, 33-35, 335-366.

[54] Sümegi, P. (1996) Az ÉK-magyarországi löszterületek összehasonlító őskörnyezeti és sztratigráfiai értékelése (Paleoenvironmental and Stratigraphic Analysis of NS Hungarian Loess Areas). Candidate Dissertation, University of Debrecen, Debrecen.

[55] Sümegi, P., Magyari, E., Daniel, P., Hertelendi, E. and Rudner, E. (1999) A kardoskúti Fehér-tó negyedidőszaki fejlődéstörténetének rekonstrukciója (Quaternary Evolution and Its Reconstruction of Lake Fehér in Kardoskút). Földtani Közlöny, 129, 479-519.

[56] Sümegi, P. (2004) The Results of Paleoenvironmental Reconstruction and Comparative Geoarcheological Analysis for the Examined Area. In: Sümegi, P. and Gulyás, S., Eds., The Geohistory of Bátorliget Marshland, Archaeolingua Press, Budapest, 301-348.

[57] Sümegi, P., Jakab, G., Majkut, P., Törőcsik, T. and Zatykó, C. (2009) Middle Age Paleoecological and Paleoclimatological Reconstruction in the Carpathian Basin. Idöjárás, 113, 265-298.

[58] Juhász, I. (2007) Comparison and Correlation of Four Pollen Sequences from the Little Balaton Region (Zalavár, Fönyed, Keszthely and Alsópáhok). In: Zatykó, Cs., Juhász, I., and Sümegi, P., Eds., Environmental Archaeology in Transdanubia (Hungary), Varia Archaeologica Hungarica 20, Budapest, 36-51.

[59] Magny, M., Mouthon, J. and Ruffaldi, P. (1995) Late Holocene Level Fluctuations of the Lake Ilay in Jura, France: Sediment and Mollusc Evidence and Climatic Implications. Journal of Paleolimnology, 13, 219-229. http://dx.doi.org/10.1007/BF00682766

[60] Holzhauser, H., Magny, M. and Zumbuühl, H.J. (2005) Glacier and Lake-Level Variations in West-Central Europe over the Last 3500 Years. Holocene, 15, 789-801. http://dx.doi.org/10.1191/0959683605hl853ra

[61] Davis, B., Brewer, S., Stevenson, T. and Juggins, S. (2001) High Resolution from Low Resolution; a New Method for Time-Series Pollen-Climate Reconstruction and Its Application in Investigating Abrupt Holocene Climate Change in Southern Europe/Mediterranean. Abstracts of PAGES-PEPIII: Past Climate Variability through Europe and Africa. 
[62] Davis, B.A.S., Brewer, S., Stevenson, A.C. and Guiot, J. (2003) The Temperature of Europe during the Holocene Reconstructed from Pollen Data. Quaternary Science Reviews, 22, 1701-1716. http://dx.doi.org/10.1016/S0277-3791(03)00173-2

[63] Magyari, E. (2002) Climatic versus Human Modification of the Late Quaternary Vegetation in Eastern Hungary. Ph.D. Dissertation, University of Debrecen, Debrecen.

[64] Kreuz, A. (1992) Charcoal from Ten Early Neolithic Settlements in Central Europe and Its Interpretation in Terms of Woodland Management and Wildwood Resources. Bulletin de la Société Botanique de France Acta Botanique, 139, 383-394.

[65] Náfrádi, K., Bodor, E., Töröcsik, T. and Sümegi, P. (2011) Vegetation History Reconstructed from Anthracology and Pollen Analysis at the Rescue Excavation of the MO Motorway, Hungary. Central European Journal of Geosciences, 3 , 358-367. http://dx.doi.org/10.2478/s13533-011-0036-0

[66] Náfrádi, K., Sümegi, P. and Törőcsik, T. (2012) Charcoal and Pollen Analyses and Vegetation Reconstruction of the Alpine Foreland in West Hungary. Central European Journal of Geosciences, 4, 592-602. http://dx.doi.org/10.2478/s13533-012-0104-0

[67] Dansgaard, W., Johnsen, S.J., Clausen, H.B., Dahl-Jensen, D., Gundenstrup, N.S., Hammer, C.J., Hvidberg, C.S., Steffensen, J.P., Sveinbjörnsdottir, A.E., Jouzel, J. and Bond, G. (1993) Climate Instability during the Last Interglacial Period Recorded in the GRIP Ice Core. Nature, 364, 203-207.

[68] Grootes, P.M., Stuiver, M.J., White, J.W.C., Johnsen, S. and Jouzel, J. (1993) Comparison of Oxygen Isotope Records from the GISP2 and GRIP Greenland Ice Cores. Nature, 36, 552-554. http://dx.doi.org/10.1038/366552a0

[69] Magny, M. (2004) Holocene Climatic Variability as Reflected by Mid-European Lake-Level Fluctuations, and Its Probable Impact on Prehistoric Human Settlements. Quaternary International, 113, 65-79. http://dx.doi.org/10.1016/S1040-6182(03)00080-6

[70] Lamb, H.H. (1995) Climate, History and the Modern World. Routledge Press, London.

[71] Stuiver, M., Grootes, P.M. and Braziunas, T.F. (1995) The GISP2 $\delta^{18}$ O Climate Record of the Past 16,500 Years and the Role of the Sun, Ocean, and Volcanoes. Quaternary Research, 44, 341-354. http://dx.doi.org/10.1006/qres.1995.1079

[72] Telford, R.J., Heegaard, E. and Birks, H.J.B. (2004) All Age-Depth Models Are Wrong: But How Badly? Quaternary Science Reviews, 23, 1-5. http://dx.doi.org/10.1016/j.quascirev.2003.11.003

[73] Szabó, P. (2002) Erdők, erdészet, erdészettörténet (Forests, Forestry, History of Forestry). Soproni Szemle, 56, 390392.

[74] Szabó, P. (2005) Woodland and Forests in Medieval Hungary. Archaeopress, Oxford. 